\title{
CRITICISMO SOCIAL COMO PRÁXIS POLÍTICA: TEORIA SOCIAL CRÍTICA, PARTICIPAÇÃO POLÍTICA E TRANSFORMAÇÃO SOCIAL-INSTITUCIONAL
}

\author{
SOCIAL CRITICISM AS POLITICAL PRAXIS: CRITICAL SOCIAL THEORY, POLITICAL PARTICIPATION \\ AND SOCIAL-INSTITUTIONAL TRANSFORMATION]
}

\author{
Leno Francisco Danner * \\ Fundação Universidade Federal de Rondônia, Brasil \\ Agemir Bavaresco ** \\ Pontifícia Universidade Católica do Rio Grande do Sul, Brasil \\ Fernando Danner *** \\ Fundação Universidade Federal de Rondônia, Brasil
}

Resumo: o artigo correlaciona criticismo social e práxis político-normativa, criticismo social como práxis político-normativa dos e pelos excluídos-marginalizados, de sentido antisistêmico e anti-institucionalista que põe por terra três pontos teórico-políticos fundamentais da Realpolitik contemporânea assumidos em cheio pelo conservadorismo político e indiretamente utilizados por teorias sociais e por filosofias políticas liberais e socialdemocratas hodiernas, a saber: uma noção lógico-técnica, não-política e não-normativa de sistema social ou instituição, que individualiza, tecniciza e despolitiza campos da vida social, tornando-os autônomos e sobrepostos em relação à práxis política fundada em normatividade social; uma compreensão do processo de modernização ocidental como auto-diferenciação, autorreferencialidade e auto-subsistência daqueles sistemas sociais lógico-técnicos que põe por terra tanto a noção de sociedade como totalidade políticonormativa quanto a centralidade da práxis política como base-instrumento dinamizadororientador da estruturação das instituições e da evolução social; um procedimentalismo institucional que é neutro, imparcial, impessoal e formal em relação às classes sociais e suas lutas, que separa de modo férreo instituições e sociedade civil, sujeitos epistemológicopolíticos institucionalizados e sujeitos epistemológico-políticos
ABSTRACT: the paper links social criticism and political praxis, social criticism as politicalnormative praxis of the excluded-marginalized and by them, with an anti-systemic and antiinstitutionalist role which puts down three fundamental theoretical-political points of the contemporary Realpolitik assumed by conservatism and indirectly used by liberal and social-democratic social theories and political philosophies, namely: a technical-logical, nonpolitical and non-normative notion of social system or institution which individualizes, technicizes and depoliticizes spheres of social life, making them autonomous and overlapped in relation to political praxis grounded on social normativity; an understanding of the process of Western modernization as selfdifferentiation, self-referentiality and selfsubsistence of those technical-logical social systems which puts down both the notion of society as political-normative totality and the centrality of the political praxis as basisinstrument which streamlines and orientates the institutional structuration and the societal evolution; an institutional proceduralism which is neutral, impartial, impersonal and formal regarding social classes and their struggles, separating strongly institutions and civil society, institutionalized epistemologicalpolitical subjects and non-institutionalized epistemological-political subjects, making political institutionalism, and from the

* Departamento de Filosofia da Fundação Universidade Federal de Rondônia. E-mail: leno_danner@yahoo.com.br ** Departamento de Filosofia e Programa de Pós-Graduação em Filosofia da Pontifícia Universidade Católica do Rio Grande do Sul (PUCRS). E-mail: abavaresco@pucrs.br *** Departamento de Filosofia da Universidade Federal de Rondônia (UNIR).E-mail:fernando.danner@gmail.com 
institucionalizados, fazendo do impersonal and apolitical proceduralism, the institucionalismo político, e partir do paradigmatic basis both to the functioning of procedimentalismo impessoal e apolítico, a the institutions themselves and to the own base paradigmática tanto para o funcionamento actuation of the social movements and citizen das instituições sobre si mesmas quanto para a initiatives in relation to institutions. From here, própria atuação dos movimentos sociais e das iniciativas cidadãs em relação às instituições. A partir disso, argumentar-se-á que somente uma práxis político-normativa anti-sistêmica e antiinstitucionalista, dos excluídos-marginalizados e por eles mesmos, em seu caráter permanente, inclusivo e participativo que a tudo politiza, pode permitir que o criticismo social como práxis política adquira um sentido críticoemancipatório, como voz-práxis das vítimas. Nesse sentido, o criticismo social como práxis político-normativa das vítimas por elas mesmas é sempre anti-institucionalista e anti-sistêmico, a tudo politizando, exigindo a participação, a inclusão, a voz-práxis dos excluídosmarginalizados como condição paradigmática para a estruturação das instituições e para a orientação da evolução social, rompendo com o institucionalismo forte e apolítico.

Palavras-Chave: Criticismo Social; Práxis Política; Instituições; Participação.

it will be argued that only an anti-systemic and anti-institutionalist political-normative praxis of the excluded-marginalized ones and by them, in a permanent, inclusive and participative sense which politicizes all, can allow that the social criticism as political praxis acquire a critical-emancipatory sense, as voicepraxis of victims. In this sense, social criticism as political-normative praxis of the victims by themselves is always anti-institutionalist and anti-systemic, politicizing all, requiring the participation, the inclusion, the voice-praxis of the excluded-marginalized as paradigmatic condition for institutional structuration and the orientation of social evolution, breaking up with the strong and apolitical institutionalism.

Keywords: Social Criticism; Political Praxis; Institutions; Participation.

\section{O OBJETO, A PRÁXIS E O SUJEITO DA CRÍTICA}

A indissolúvel ligação entre teoria e prática é a base a partir da qual a abordagem em ciências humanas e sociais é estruturada, dinamizada e definida. Isso significa que se teoriza para politizar e se politiza para teorizar, em um movimento imbricado e mutuamente dependente que não admite um estilo de objetividade científica muito comum mas também muito problemático - no que diz respeito à constituição e ao funcionamento do campo das ciências naturais e por parte delas. No caso, a profunda politização da teoria social e a profunda teorização da política cotidiana demonstram o quanto, para além daquele pouco claro ideal de objetividade científica próprio às ciências da natureza, é importante e necessário politizar-se radicalmente o exercício teórico de enquadramento, interpretação e fundamentação da Realpolitik, ao mesmo tempo em que se a teoriza efetivamente, posto que ela não é um exercício espontâneo, desinteressado e irreflexivo, sua constituição, legitimação e dinamização ao longo do tempo não acontecem por acaso, senão que são resultado de ação reflexiva e intencionada, de uma práxis que possui carnalidade e politicidade. Ora, isso nos leva a percebermos a centralidade dos três momentos fundamentais, dos três passos metodológicoprogramáticos basilares para a constituição e para a realização do criticismo social enquanto práxis política: o objeto da crítica, a práxis da crítica e o sujeito da crítica, que são (a) o campo do político, isto é, a esfera da reprodução sociocultural, (b) o tipo de ação e/ou caminho assumido politicamente para tal (e certamente o tipo de política que poderia enquadrar, interpretar e transformar o horizonte da reprodução sociocultural, a assim chamada Realpolitik) e (c) o sujeito epistemológico-político da práxis política, da transformação social. A tematização desses três momentos imbricados e mutuamente dependentes também pressupõe o e implica no fato de que o âmbito teórico-político das ciências humanas e sociais é normativo, ético-político, não cabendo aqui neutralidade, formalidade, imparcialidade e 
impessoalidade, muito menos tecnicalidade - trata-se de um ideal regulador, este da neutralidade axiológica, da técnica pura em termos de pesquisa e da impessoalidade do sujeito epistêmico-político, que não se coaduna com a pungência e a dramaticidade das lutas sociais e dos sujeitos políticos em termos de Realpolitik, que não faz jus à politicidade-carnalidade dos sujeitos epistemológico-políticos e de suas lutas sociais em termos de Realpolitik.

O primeiro ponto central para entendermos o sentido, a constituição e a dinamização do criticismo social, portanto, consiste na intrínseca correlação e mútua dependência entre epistemologia e política, entre teoria e prática, conforme dissemos acima, correlação e dependência entre teoria e prática que representam uma já clássica noção na filosofia e na sociologia acadêmicas desenvolvidas na Europa entre os séculos XIX e XX, e assumidas ainda hoje como mote basilar das investigações sociais e da fundamentação-dinamização do campo do político por posições como a Escola de Frankfurt (Adorno, Horkheimer, Marcuse, Habermas, Honneth, Forst, Jaeggi, Brunkhorst etc.) e a filosofia francesa contemporânea (Bataille, Foucault, Derrida, Sartre etc.), principalmente quando se fala na continuação daquela tradição filosófico-sociológica, profundamente imbricada com movimentos políticos e revoluções sociais (pense-se na correlação estabelecida entre a filosofia francesa do século XVIII e a Revolução Francesa de 1789, assim como na profunda conexão entre marxismo e movimentos proletários desde meados do século XIX em diante ou mesmo o mútuo suporte entre marxismo e Revolução Russa de 1917, ou o maio de 1968 e a filosofia franco-alemã), assim como teorias pós-coloniais e decoloniais e os movimentos de emancipação latinoamericanos e africanos, e as teorias ligadas às minorias - feministas, queer - e as lutas de grupos marginalizados que elas embasam, representam, assume, como mulheres e LGBTTs). Por outro lado, não podemos nos esquecer que criticismo social e atuação epistemológicopolítica cotidiana engajados fazem parte de qualquer sociedade-comunidade: um exemplo, explicitado de passagem logo acima, pode ser percebido nos movimentos emancipatórios latino-americanos e africanos e, mais especificamente no âmbito da filosofia, na vasta e muito profícua tradição da filosofia latino-americana e africana em termos de tematizaçãoentendimento da situação-sujeito periférico e colonizado, inclusive como uma reação às posições epistemológico-políticas produzidas no âmbito da filosofia e da sociologia europeias (cf.: Dussel, 1993, 1998; Bondy, 1968; Fanon, 1968; Mbembe, 2001, 2014). Outro exemplo, já comentado acima, é o das mulheres e dos grupos LGBTTs, que utilizam-se de teorias feministas e queer para fundamentar sua voz-práxis (cf.: Butler, 2003, 2004; Riley, 1988; Young, 1990; Irigaray, 1992; Cornell, 1998; Butler \& Scott, 1992; Fraser, 2013; Benhabib \& Cornell, 1987; HAGGERTY \& MCGARRY, 2007). De todo modo, estes exemplos querem ressaltar exatamente o fato de que epistemologia e política, o teorizar e o agir se assim se quiser, se fazem como práxis cotidiana e por sujeitos epistemológico-políticos cotidianos em suas lutas por hegemonia e a partir dos contrapontos gerados por estas, em todos os lugares e sob todas as formas e a partir de múltiplos sujeitos epistemológico-políticos.

Ora, com isso surge um segundo ponto importante em termos de criticismo social, que é o fato de que, para utilizar um termo de Thomas Piketty em seu magnífico $O$ capital no século XXI, tudo é político, tudo é política (cf.: Piketty, 2014, p. 27). Com efeito, como vimos dizendo, o âmbito, a dinâmica e o sujeito da atuação crítica situa-se na práxis que tem sua gênese e sua incidência e seu mote na Realpolitik, a partir da tematização-participação de sujeitos epistemológico-políticos que questionam formas de status quo, estruturações institucionais e práticas sociais intersubjetivas consideradas injustas - daí o sentido políticonormativo da Realpolitik, da práxis teórico-política e, evidentemente, dos sujeitos epistemológico-políticos dessa mesma Realpolitik. Aqui, o fundamento de todo e qualquer criticismo social consiste na politização efetiva, total por assim dizer, de todo o campo societal-cultural-institucional, de suas dinâmicas e de seus sujeitos epistemológico-políticos. Só se pode criticar algo porque ele é político (e não técnico e/ou essencialista e naturalizado), assim como só se pode criticar e agir teórico-politicamente ao reconhecer-se tanto a existência de sujeitos epistemológico-políticos que constroem-dinamizam-determinam designs institucionais e rumos da evolução social quanto o fato de que, por causa disso, esse campo societal-cultural-institucional é construção cotidiana não-neutra, não-imparcial e não- 
impessoal, dependente das lutas sociais entre sujeitos epistemológico-políticos com alcance macro, com sentido estrutural, superdimensionado. Portanto, aqui, a politização plena da sociedade, das instituições e dos sujeitos epistemológico-políticos recusa diretamente a evolução-constituição espontânea da sociedade, a impessoalidade-formalidade-neutralidade dos sujeitos epistemológico-políticos e o sentido lógico-técnico, não-político e não-normativo

14 das instituições - recusa, inclusive, qualquer sentido essencialista e naturalizado dessas instituições, dos sujeitos epistemológico-políticos e da constituição-evolução da sociedade. Em princípio, a evolução social, as lutas sociopolíticas e a estruturação das instituições podem ser explicadas-enquadradas-transformadas pelas lutas sociais e seus contrapontos entre classes sociais antagônicas, entre sujeitos epistemológico-políticos antagônicos, ou seja, ela pode ser explicada-transformada teórico-politicamente porque ela é uma construção dos sujeitos epistemológico-políticos da práxis enquanto sujeitos que agem e lutam em um sentido estrutural como classes sociais. Isso quer dizer que a evolução social e a estruturação institucional não acontecem do nada, não são espontâneas e nem neutras e nem impessoais relativamente às classes sociais e suas lutas por poder e por hegemonia.

Com isso, já temos alguns pontos fundamentais para pensarmos sobre a questão do criticismo social como imbricação e mútua dependência entre epistemologia e política: (a) ele pressupõe e aponta para a politização total da sociedade, das instituições e dos sujeitos epistemológico-políticos, recusando uma compreensão lógico-técnica ou instrumental das instituições; (b) ele concebe a compreensão, fundamentação e transformação social como práxis teórico-política encarnada e atuante, recusando a despolitização, a espontaneidade e tecnicalidade da evolução social; (c) ele afirma que as lutas sociais entre classes sociais antagônicas são respectivamente a arena-dinâmica e o sujeito epistemológico-político fundamental da evolução social e da estruturação institucional, recusando, como consequência, o institucionalismo forte como arena despolitizada e impessoal para a constituição-legitimação-realização da evolução social e as elites institucionais enquanto sujeitos imparciais, neutros, formais e impessoais basilares da estruturação e dinamização das instituições em primeiro lugar e da evolução social em segundo; (d) e ele parte da dramaticidade e da pungência tanto dos processos de constituição-legitimação-evolução social e institucional quanto dos sujeitos epistemológico-políticos e de seus confrontos, recusando certas noções idílicas de ativismo e de representação políticos, bem como, para utilizar um termo de Herbert Marcuse, de tolerância pura em termos de práxis teórico-política (cf.: Marcuse, 1970). As situações de marginalização e de opressão sociais, assim como a participação ativa dos sujeitos epistemológico-políticos dentro do horizonte da práxis e sob a forma de luta por poder-hegemonia, são pungentes, dramáticas e decidem sobre as dinâmicas de evolução social e as formas de estruturação institucional, moldando, portanto, a sociedade, suas instituições, seus códigos e suas relações. Nesse sentido, o criticismo social enquanto práxis política necessita politizar a interpretação-ação, deve buscar tematizar-legitimar sujeitos epistemológico-políticos e precisa orientar-projetar a luta-hegemonia.

Há mais uma característica fundamental do criticismo social que se ramifica em uma dupla dinâmica: a interpretação da Realpolitik e sua consequente aplicação-atuação política. Toda ação político-normativa (assim como a ação como um todo) parte de uma interpretação do cotidiano, da Realpolitik. Essa interpretação assume-se como verdadeira, como objetiva em relação ao fato social patológico, ao problema político e ao sujeito epistemológico-político injusto ou totalitário. Da mesma forma, seu diagnóstico e sua proposição, assim como os sujeitos epistemológico-políticos que esse criticismo social legitima, assumem, a partir daquela interpretação objetiva inicial do problema e dos responsáveis pelo problema, legitimidade para serem impostos e realizados e, naturalmente, para agirem na práxis. A rigor, a crítica e sua consequente ação política emancipatória creditam-se como justificadas seja por causa da capacidade objetiva e verdadeira do diagnóstico, seja por causa da proposição que projeta e realiza. Da mesma forma, o sujeito epistemológico-político da crítica-ação concebese como legitimado a reivindicar-lutar contra a situação de injustiça diagnosticada, que certamente lhe afeta ou afeta alguém do cotidiano. Ora, a interpretação objetiva do fatoproblema sociopolítico, a construção do diagnóstico e das proposições em torno a ele, além da 
legitimação dos sujeitos epistemológico-políticos construtores desse diagnóstico e realizadores da ação político-emancipatória, tudo isso constitui um dos grandes desafios - e certamente o mais excitante dos desafios - assumido pela teoria social e pela filosofia política, mas também pela ação cotidiana em termos de Realpolitik ao longo do tempo. Isso abre espaço, por exemplo, conforme refletiremos mais adiante, para um ideal de objetividade teórico-política que possa ser aplicado socialmente para além da neutralidade, imparcialidade e impessoalidade científicas em particular e institucionais de um modo mais geral. Não por acaso, o ideal de objetividade teórico-política das lutas sociais contrapõe-se diretamente àquele caricato método imparcial, neutro, formal e impessoal próprio das ciências da natureza, assim como se choca diretamente com um modelo político e com um paradigma normativo definidos-dinamizados enquanto procedimentalismo institucional imparcial, neutro, formal e impessoal frente aos sujeitos sociopolíticos como classes sociais e suas lutas por hegemonia.

Ora, falamos, no parágrafo anterior, que há uma interpretação teórico-política de certos problemas sociais e de certos sujeitos epistemológico-políticos não-emancipatórios, por assim dizer, presentes na Realpolitik, o que enseja, como conseqüência, uma ação política emancipatória dinamizada por sujeitos epistemológico-políticos emancipatórios - a ação é emancipatória porque, correlatamente, como condição disso, interpreta de maneira objetiva o fato social e os sujeitos políticos problemáticos, assim como, enquanto conseqüência, legitima sujeitos epistemológico-políticos críticos a transformarem politicamente essa mesma situação de injustiça por meio do enfrentamento em relação aos sujeitos epistemológico-políticos nãoemancipatórios. Nesse sentido, quem é o sujeito que tematiza-intepreta? Quem é o sujeito da crítica? O sujeito que interpreta é o mesmo sujeito que age politicamente? O que ele possui de especial em termos normativos que lhe permite assumir uma interpretação crítica (porque objetiva) e realizar uma ação emancipatória e transformadora (porque moral e normativamente justificada) em relação às patologias sociais e aos sujeitos epistemológico-políticos nãoemancipatórios?

Primeiro: o sujeito da crítica e da emancipação é marginalizado e violentado por estruturas societais-culturais-institucionais de opressão e de exclusão, assim como deslegitimado por paradigmas epistemológico-políticos oficiais, em geral institucionalizados, por assim dizer. Dentro destas estruturas societais-culturais-institucionais e a partir destes paradigmas epistemológico-políticos institucionalizados, as vítimas sempre serão vítimas, os excluídos sempre serão excluídos e a marginalização, de um modo geral, sempre será marginalização: eles deslegitimam quaisquer crítica, participação e transformação incisivas exatamente por apagarem a politicidade radical e as lutas de classe próprias a cada contexto vital, societal, cultural, institucional. Não por acaso, nesse sentido, o sujeito da crítica é ou está compromissado diretamente com o oprimido, com o marginalizado, com o excluído, assumindo diretamente uma postura de reformulação epistemológica e de oposição-luta política em relação aos grupos sociais não-emancipatórios e aos paradigmas epistemológicopolíticos não-críticos, despolitizadores. Segundo: o excluído, marginalizado e oprimido apresenta, como característica especial que lhe garante potencial de crítica e de emancipação (pelo menos para si mesmo, para seu grupo) exatamente essa sua situação de marginalização, opressão e exclusão, que permite um duplo passo: perceber quais estruturas institucionais, paradigmas epistemológico-políticos e classes sociais sustentam-geram-legitimam tal situação de injustiça; e assumir, por causa dessa sensibilidade, dessa carnalidade-politicidade da própria situação de injustiça, o papel de sujeito que fala e luta teórico-politicamente contra tais estruturas institucionais, paradigmas epistemológico-políticos e classes sociais. $\mathrm{O}$ marginalizado fala a partir de uma situação fática que é legitimada e realizada a partir da Realpolitik e desde uma fundamentação epistemológico-política assumida e realizada por classes sociais, por sujeitos epistemológico-políticos de carne e osso, vivos (mais uma vez, isso prova a ligação intrínseca entre teoria e prática). E esse mesmo marginalizado luta a partir de uma situação fática de opressão e de violência contra aquelas estruturas institucionais, paradigmas epistemológico-políticos e classes sociais não-emancipatórios, despolitizadores.

Aqui, a objetividade e a justificação são dadas, pelo menos ao marginalizado, por causa de sua condição epistemológico-política de vítima da marginalização, mas ao mesmo tempo 
de denunciante dela; de objeto de exploração e de marginalização, mas ao mesmo tempo de sujeito da resolução desses problemas; de sujeito epistemológico-político negado e violentado, mas ao mesmo tempo como sujeito epistemológico-político efetivo - provavelmente o sujeito epistemológico-político par excellence da práxis - do criticismo e da transformação sociopolíticas. E por estar submetido a uma situação de negação, de marginalização e de

16 exclusão que ele pode interpretar objetivamente, denunciar criticamente e agir politicamente em relação ao contexto, ao paradigma epistemológico-político e aos sujeitos epistemológicopolíticos legitimadores, geradores e dinamizadores da exclusão. Isso prova novamente a necessidade que a crítica social tem de politizar tudo radicalmente, desde estruturas institucionais e paradigmas epistemológico-políticos institucionalizados chegando-se às classes sociais e sua Realpolitik. E isso prova o quanto a crítica social e a práxis política emancipatória são o discurso-práxis das vítimas da exclusão e da marginalização, a base paradigmática que lhes possibilita expressarem-se, interpretarem e agirem sobre sua situação e como contraposição aos grupos sociopolíticos não-emancipatórios e a seus paradigmas epistemológico-políticos institucionalizados acríticos. Somente essa localização e esse comprometimento com o contexto e o papel normativo-políticos dos marginalizados e como discurso-práxis deles sobre eles mesmos podem permitir-possibilitar à crítica social efetivamente reverter-se em práxis política emancipatória, rompendo com e desconstruindo paradigmas epistemológico-políticos não-emancipatórios, despolitizadores da situação do excluído-marginalizado-oprimido.

É importante salientar-se, ainda, que, conforme já delineado de passagem no início desse texto, o criticismo social enquanto práxis política ocorre em todos os lugares e sob variadas formas, o que significa que o sujeito da crítica enquanto sujeito da ação assume diferentes localização sociopolíticas e se manifesta-age de múltiplos prismas: muitas vezes, a crítica social é baseada em e dinamizada por convicções religiosas (por exemplo: Mahatma Gandhi, Martin Luther King, teologia da libertação etc.); outras vezes, ela é uma crítica de cunho cultural (movimentos feministas e LGBTT, maio de 68, movimentos de descolonização); e outras tantas ela é diretamente política (pensemos na Revolução Chinesa, na Revolução Cubana ou nas já citadas Revolução Russa e Revolução Francesa etc.). Ora, a multiplicidade dos sujeitos epistemológico-políticos da práxis e como práxis significa, consequentemente, a multiplicidade de caminhos e de estratégias programático-políticas no que diz respeito à fundamentação e à realização correlata e mutuamente dependente da crítica social e da ação política. Múltiplos são os caminhos do enquadramento crítico das situações de injustiça e dos sujeitos epistemológico-políticos não-emancipatórios, variadas são as lutas sociais, heterogêneas são as formas de fala-ação dos excluídos. Essa dupla e imbricada condição - pluralidade de sujeitos epistemológico-políticos e de sua práxis críticoemancipatória - foi com razão explicitada por muitas posições filosófico-sociológicas contemporâneas, desde as já citadas Escola de Frankfurt e filosofia francesa contemporânea e teologia da libertação e filosofias latino-americana e africana, passando-se pela filosofia feminista e pela teoria queer e chegando-se ao liberalismo político contemporâneo, com sua controvérsia em torno ao comunitarismo e ao individualismo. Nota-se, aqui, que a crítica social é plural por causa da multiplicidade de sujeitos epistemológico-políticos e de suas manifestações, o que significa um poderoso incremento no que tange a se constituir teorias sociais críticas e ações políticas emancipatórias, que já não encontram mais apenas um sujeito epistemológico-político como seu destinatário e nem se processam-dinamizam apenas de um modo. O sujeito epistemológico-político excluído é plural, suas vozes são plurais, assim como suas lutas - talvez aqui esteja, diga-se de passagem, uma das estratégias fundamentais das lutas sociais contemporâneas, no sentido de que poderiam buscar com cada vez mais intensidade a aglutinação desses múltiplos sujeitos epistemológico-políticos excluídos, com seus contextos plurais seja de exclusão, seja como potencial de crítica e de libertação, possibilitando-se um concerto entre suas lutas mais particularizadas.

Essas observações nos permitem perceber mais dois elementos importantes pressupostos-assumidos pelo criticismo social, uma herança fundamental da filosofia e da sociologia, a saber, de que tanto a sociedade e suas instituições quanto os sujeitos 
epistemológico-políticos da Realpolitik possuem um sentido macro-estrutural, uma orientação, alcance e influência macro-estruturais. Em outras palavras, são super-instituições e supersujeitos que, a partir de seu funcionamento e de sua luta, influenciam dinâmicas sociais de amplo alcance, que perpassam a sociedade e seus sujeitos epistemológico-políticos como um todo. A primeira e fundamental consequência dessa constatação está exatamente em desconstruir a impessoalidade, a neutralidade e a individualização tanto das instituições sociais quanto, mais ainda, dos sujeitos epistemológico-políticos. A atuação das instituições, na medida em que elas são super-estruturas que coordenam todo um campo da reprodução social, influindo diretamente em outros (pense-se nas duas grandes instituições da modernização ocidental, o mercado capitalista e o Estado burocrático-administrativo) e definindo seus contornos e resultados basilares, tem consequências diretamente políticas e implica na orientação da constituição do status quo de amplos sujeitos epistemológico-políticos e na dinamização da balança de poder entre eles. Da mesma forma, aqui, é exatamente pelo fato de que a sociedade e suas instituições são macro-estruturas às quais se é possível constatar objetivamente e avaliar-se e enquadrar-se normativamente que se pode construir uma teoria social crítica que é crítica do social, da Realpolitik, fundamentando-se, legitimando-se, como conseqüência, uma práxis política que é emancipatória e transformadora em relação ao social, às patologias psicossociais, à Realpolitik. Aqui, a causa dos problemas sociais não está no indivíduo fracassado ou patológico, pura e simplesmente, ou mesmo em estruturas-sujeitos anônimos e impessoais que atuam em um sentido não-estrutural, não-intersubjetivo, mas sim em instituições e em sujeitos epistemológico-políticos superdimensionados, capazes de determinar configurações sociopolíticas abrangentes e de agir coletivamente. É nesse sentido, aliás, que o grosso das teorias políticas liberais não possui teoria social como seu substrato, posto que partem teoricamente e centram suas análises politicamente na correlação entre individualismo metodológico e impessoalidade-imparcialidade institucional, pontos esses que não fazem jus tanto à noção de instituição como macro-estrutura axiológica e programáticooperacional que gerencia e determina a configuração e a dinâmica de campos específicos da evolução social quanto à noção de classe social enquanto macrossujeito epistemológicopolítico que, em suas lutas por hegemonia, configura a atuação objetiva das instituições, tornando-se, essa classe mesma, em sujeito epistemológico-político objetivo, com carnalidadepoliticidade, rompendo com o individualismo metodológico e com a impessoalidadeimparcialidade institucional.

A noção de sujeito epistemológico-político da constituição-transformação social como classe social em sentido coletivo, macro-estrutural, em verdade, é o segundo elemento fundamental assumido-utilizado pelo criticismo social em suas leituras e proposições relativamente à sociedade e suas instituições como macro-estruturas, assim como aos sujeitos epistemológico-políticos presentes na sociedade, na práxis. Primeiro de tudo, a classe social dá a ideia de uma ação coletiva, que aglutina diferentes indivíduos e grupos sociais desde um objetivo normativo-político e metodológico-programático comum, o que lhes confere, utilizando termos já clássicos para se compreender o conceito de classe social, vontade e consciência comum, minimamente unitária em termos de ação epistemológico-política. A transformação social necessita de ação coletiva, de amplo aspecto, exatamente pelo sentido macro-estrutural da sociedade e de suas instituições. Aquele ditado clássico, de que uma andorinha só não faz verão, certamente possui muito sentido quando falamos em transformação social desde a práxis política, desde a participação política. As múltiplas vozes e ações precisam assumir um ponto comum, uma dinâmica comum: somente assim elas mudam comportamentos, direcionam sujeitos epistemológico-políticos e, com isso, reorientam a constituição-atuação das instituições. Segundo, a noção de classe social enquanto macrossujeito epistemológico-político nos parece interessante por suas duas contraposições básicas. (a) Ela ataca diretamente a individualização e o anonimato dos sujeitos epistemológico-políticos, assim como sua consequência, a impessoalidade e imparcialidade das instituições sociopolíticas. E (b) ela recusa o caráter lógico-técnico, não-político e nãonormativo dessas mesmas instituições sociopolíticas, de sua constituição, de seu funcionamento, de sua programação e de sua administração ao longo do tempo. Ora, tanto a 
individualização-anonimato dos sujeitos epistemológico-políticos quanto o sentido lógicotécnico das instituições sociopolíticas levam a uma poderosa - às vezes a uma definitiva despolitização seja dos sujeitos epistemológico-políticos, seja dessas instituições sociopolíticas, no sentido de que existiriam amplos campos e dinâmicas da reprodução social que, por serem particularizados e impessoais, não poderiam ser enquadrados político-

18 normativamente, na medida em que são apenas lógico-técnicos e particulares. Com isso, em se afirmando a individualização-anonimato dos sujeitos epistemológico-políticos constituintes de uma dada sociedade e a impessoalidade-imparcialidade das instituições dinamizadoras dessa mesma sociedade, pode-se apontar - como o faz, por exemplo, o conservadorismo - para o fato de que não se pode politizar totalmente a constituição, a legitimação e a evolução das instituições sociopolíticas e o entendimento-atuação dos sujeitos epistemológico-políticos. Aqui, nem tudo é político, nem tudo é política. Ora, mas quem determina o que é e o que não é político, o que é e o que não é política? Esse é o ponto nodal: somente de modo políticonormativo e como luta-hegemonia baseada em motivos político-normativos se pode definir o que é e o que não é político, o que é e o que não é política. Não existe um fundamento essencialista e naturalizado que determine isso, e certamente os fundamentos - essencialistas e naturalizados ou não - dependem exatamente da práxis dos sujeitos epistemológico-políticos. Da mesma forma, até fundamentos essencialistas e naturalizados são políticos e apontam para conseqüências, ações e sujeitos políticos. Na história da filosofia e da teologia, por exemplo, o sentido e as conseqüências político-normativas dos fundamentos essencialistas e naturalizados são claros e diretos, inquestionáveis - ao contrário de apontarem para uma esfera de neutralidade, impessoalidade e tecnicalidade, eles enfatizam-legitimam exatamente a politicidade e a normatividade dos valores, das ações e dos sujeitos epistemológico-políticos. De todo modo, o que queremos significar é que tudo é político, tudo é política, de forma que somente se pode definir o que e quem é ou não é político e o que e como se é ou não é política por meio da politização, da ação política, da imposição-hegemonia política. É nesse sentido que falamos, no texto, de teoria social como politizando fortemente as instituições, suas dinâmicas, seus valores, suas relações, os processos sociais e os sujeitos epistemológicopolíticos. E a pergunta acima - o "Quem define-determina o que é e o que não é político, o que é e o que não é política?" - aponta exatamente para esse sentido superdimensionado e abrangente dos sujeitos epistemológico-políticos como classe social, que constroem, dinamizam e orientam, desde uma práxis epistemológico-política estrutural, as instituições e o tipo de vinculação social que elas estabelecem-geram ao longo do tempo. Sem esses sujeitos políticos superdimensionados como classes sociais seria muito difícil pensar-se transformações ou pelo menos contrapontos aos grupos e posições institucionais hegemônicos em uma dada sociedade e mais além.

Note-se, aliás, que, conforme pensamos, os dois grandes desafios teórico-políticos fundamentais para uma teoria social crítica que é a voz-práxis normativo-política dos excluídos e por parte desses mesmos excluídos são exatamente a individualização-anonimato dos sujeitos epistemológico-políticos e a impessoalidade-imparcialidade das instituições sociopolíticas, assumidos pelo conservadorismo em ascensão na contemporaneidade como pontos programático-metodológicos e normativos fundantes em termos teórico-políticos, pois, como já dissemos de passagem acima, esses dois pontos, correlatos e mutuamente imbricados, levam à despolitização dos sujeitos epistemológico-políticos e à tecnicalidadeinstrumentalidade-apoliticidade das instituições sociopolíticas. Nesse sentido, no primeiro caso, os sujeitos epistemológico-políticos perdem a capacidade de agir coletivo, assim como não podem ser entendidos em sentido estrito como artífices da evolução social e da configuração institucional, a não ser indiretamente e em um sentido não-messiânico; no segundo caso, as instituições são estruturas lógico-técnicas imparciais, neutras, formais e impessoais que centralizam e monopolizam campões específicos da reprodução social, autonomizando-os (porque tecnicizando-os e instrumentalizando-os) relativamente ao restante da sociedade, com isso despolitizando-os. Ainda no primeiro caso, o individualismo metodológico coloca sob os ombros do indivíduo particular, incapaz de uma práxis política estrutural e não-possuidor de uma perspectiva messiânica em relação à sociedade como 
totalidade, o seu próprio destino pessoal, mas desligado das orientações estruturais dadas pelas instituições; já no segundo caso, instituições lógico-técnicas não possuem nenhum cunho normativo-político e nem capacidade de ações estruturais para além de seu campo, não podendo ser responsabilizadas político-normativamente e nem transformadas a partir de critérios e práxis político-normativos. Impessoalidade, imparcialidade, neutralidade, formalidade, anonimato e espontaneidade são termos fundamentais assumidos a partir dessa dupla afirmação do conservadorismo relativamente aos sujeitos epistemológico-políticos individualizados-anônimos e às instituições lógico-técnicas. Com isso, o ideal regulador e programático-metodológico de tal posição aponta sempre para a afirmação da avaliação lógico-técnica e meritocrática seja da estruturação institucional, seja da avaliação do status quo, o que lhes retira a politização e o enquadramento normativos necessários para a realização do criticismo social. Da mesma forma, a individualização-anonimato dos sujeitos epistemológico-políticos lhes retira a capacidade de assumirem-dinamizarem como classe social uma práxis política com contornos intersubjetivos e estruturais, substituindo essa noção de classe social pelo individualismo metodológico como o sujeito epistemológico-político por excelência. Aqui, a teoria social crítica ficaria sem o sujeito epistemológico-político da crítica e da emancipação (a classe social), sem o objeto da crítica-transformação (a sociedade e suas instituições como macro-estruturas) e sem a práxis da crítica-transformação (a ação política). Não por acaso, como vimos dizendo, há um retorno daqueles conceitos acima mencionados impessoalidade, imparcialidade, neutralidade, formalidade, anonimato e espontaneidade - na teoria política e econômica à direita e mesmo à esquerda como base da minimização da política e superestimação tanto do individualismo metodológico quanto do entendimento lógico-técnico das instituições sociopolíticas próprios às sociedades complexas contemporâneas e à globalização de um modo mais geral, e como herança da modernização ocidental e do entendimento dessa mesma modernização ocidental desenvolvido-assumido por teorias políticas liberais e social-democratas hodiernas.

É por isso que para o criticismo social enquanto práxis política é questão de vida e de morte o assumir três noções teórico-políticas fundamentais, como o são (a) a de sociedade como totalidade político-normativa, (b) a de instituições como estrutura-práxis políticonormativa e (c) a de classe social como macrossujeito epistemológico-político geradordinamizador da evolução social e da constituição-legitimação institucional. Trata-se de uma reação fundamental a uma noção de modernização ocidental e a uma compreensão das instituições sociopolíticas e dos sujeitos epistemológico-políticos muito em voga da filosofia política liberal e social-democrata e na teoria social de hoje, tanto à direita (Hayek, Friedman e Nozick, por exemplo) quanto na nova esquerda (Rawls, Habermas e Giddens, por exemplo), que as compartilham como um todo ou pelo menos partes dela. Primeiro, a noção de modernização ocidental como auto-diferenicação, autorreferencialidade, auto-subsistência e autonomia de sistemas sociais ou instituições lógico-técnicos, não-normativos e não-políticos, que se emancipam da sociedade civil e de seus sujeitos epistemológico-políticos, adquirindo exatamente esse cunho lógico-técnico ou instrumental marcado por um procedimentalismo imparcial, neutro, formal e impessoal que é basicamente interno aos próprios sistemas sociais, assumido por seus técnicos e elites institucionais. Aqui, as instituições centralizam, monopolizam e administram campos específicos da evolução social desde dentro delas mesmas, como uma prática-dinâmica-procedimento fundamentalmente interno a elas mesmas e de prisma lógico-técnico, não-político e não-normativo, fechando-se à politização desses mesmos sistemas sociais desde fora, por sujeitos e práticas epistemológico-políticos que questionam tanto a autorreferencialdidade e a auto-subsistência quanto a despolitização e a tecnicalidade desses mesmos sistemas sociais. Nessa noção conservadora de modernização ocidental desenvolvida em termos de teoria de sistemas, as instituições ou sistemas sociais modernos não são, em primeira mão, estruturas-sujeitos-práxis político-normativa, mas sim lógico-técnica. Da mesma forma, esses sistemas sociais não fazem parte de um todo sócioinstitucional maior, de base político-normativa, senão que são independentes da sociedade como totalidade político-normativa, diferenciados e mesmo opostos em relação a ela, recusando, por isso mesmo, sua intervenção-enquadramento desde fora e a partir de 
fundamentos político-normativos, por sujeitos não-institucionais.

Segundo, a noção de sujeito epistemológico-político individualizado e anônimo compartilhada pelo liberalismo político à esquerda e à direta (Hayek, Nozick e Rawls) e pela social-democracia representada pela nova esquerda (Habermas e sua retomada de uma socialdemocracia reflexiva e Giddens e sua defesa da terceira via enquanto correlação entre

20 neoliberalismo e social-democracia). Para ambos, liberalismo e social-democracia, liberalismo conservador e nova esquerda, as sociedades complexas contemporâneas são marcadas, como vimos dizendo, pela individualização e pelo anonimato dos sujeitos epistemológico-políticos, que já não podem mais ser concebidos ao estilo de classes sociais enquanto macrossujeitos epistemológico-políticos que, através de suas lutas por hegemonia, dinamizam a constituição institucional e dão contornos estruturais aos processos de evolução social. Os sujeitos epistemológico-políticos das sociedades democráticas complexas contemporâneas são totalmente individualizados e anônimos, incapazes de agir em sentido estrutural, incapazes, por isso mesmo, de assumir uma noção crítico-emancipatória de normatividade social em nome da sociedade como um todo e, como conseqüência, de realizar uma práxis política emancipatória que, fundada na e dinamizada pela luta de classes, enquadra as instituições sociopolíticas e suas elites institucionais, principalmente no sentido de pôr em xeque aquela que pensamos ser a mais perigosa correlação e mútua dependência da política conservadora hodierna (acriticamente assumida pela nova esquerda), a saber, a correlação e mútuo suporte entre institucionalismo forte (sistemas sociais ou instituições autorreferenciais e autosubsistentes de cunho lógico-técnico, não-político e não-normativo, que, desde uma dinâmica fundamentalmente interna assumida por elites e técnicos institucionais, centralizam e monopolizam a constituição, a legitimação e a evolução de campos específicos da evolução social, despolitizando-os e tornando-os autônomos em relação à crítica social e à práxis política, e deslegitimando os sujeitos epistemológico-políticos emancipatórios e suas lutas desde a sociedade civil), partidos políticos e oligarquias econômicas afirmadores da teoria de sistemas como base para a compreensão da sociedade, de suas instituições, do funcionamento dessas instituições e da correlação entre sistemas sociais e sociedade civil.

Em suma, o criticismo social enquanto práxis política necessita, como contraposição ao liberalismo político e à social-democracia, (a) afirmar a completa politicidade das instituições e dos sujeitos epistemológico-políticos, assim como (b) sua férrea imbricação a uma noção político-normativa de sociedade enquanto totalidade social, de modo a superar a noção lógico-técnica de modernização ocidental, marcada por sistemas sociais não-políticos e não-normativos, fundamentalmente autorreferenciais, auto-subsistentes e autônomos em relação à crítica social e à práxis política escoradas em e dependentes de uma noção vinculante de normatividade social; de modo a superar também, por meio do entendimento desses sujeitos epistemológico-políticos da evolução social e da dinamização institucional como classes sociais enquanto super-sujeitos políticos, uma noção de procedimentalismo jurídicopolítico imparcial, neutro, formal e impessoal que serve tanto para fundamentar o tipo de práxis política democrática efetivo para as sociedades complexas contemporâneas, de modernização burocrático-capitalista, quanto para entender-se e enquadrar-se o funcionamento dos próprios sistemas sociais modernos, no caso o Estado e o mercado. Os sujeitos epistemológico-políticos enquanto classes sociais apontam diretamente para a politização da evolução social e da estruturação institucional, imbricando fortemente sociedade civil e instituições, desconstruindo aquele sentido lógico-técnico, imparcial, neutro, formal e impessoal, anônimo e espontâneo atribuído pelo conservadorismo àquelas instituições modernas. Isso evitaria, por conseguinte, a sobreposição e a independência dos sistemas sociais em relação às classes sociais e suas lutas político-normativas por hegemonia.

Como vimos dizendo, entender-se as instituições modernas como autorreferenciais e auto-subsistentes, como sendo constituídas por um procedimentalismo imparcial, neutro, formal e impessoal que é basicamente interno e lógico-técnico, não-político e não-normativo, assumido e centralizado por técnicos e elites institucionais, equivale a despolitizar esses mesmos sistemas sociais, tornando-os autônomos e sobrepostos à sociedade civil, às classes sociais e suas lutas. Aqui, as instituições apareceriam como estruturas-sujeitos-dinâmicas 
puras, basicamente instrumentais, técnicas, sem qualquer politicidade-carnalidade. Ora, como é possível criticismo social e práxis política emancipatória - que estão baseados em normatividade social e que politizam esses mesmos sistemas sociais - relativamente a sistemas sociais lógico-técnicos, autorreferenciais e auto-subsistentes, não-políticos e não-normativos? Como é possível que a crítica social e a práxis política possam enquadrar e transformar de fora (das instituições) para dentro (das instituições) sistemas sociais lógico-técnicos dotados de um procedimentalismo imparcial, impessoal, neutro e formal? Por fim, como é possível conceberse sujeitos epistemológico-políticos institucionais sem constituição político-normativa, realizadores daquele procedimentalismo imparcial, neutro, formal e impessoal como basedinâmica da evolução social e da constituição-legitimação institucional? Em ambos os casos sistemas sociais lógico-técnicos, autorreferenciais e auto-subsistentes e sujeitos epistemológico-políticos anônimos e individualizados, com o consequente procedimentalismo imparcial, neutro, formal e impessoal como dinâmica fundamental do auto-funcionamento e da auto-justificação dos sistemas sociais - a política perde qualquer possibilidade de enquadrar-transformar esses mesmos sistemas sociais, assim como os sujeitos epistemológicopolíticos advenientes da sociedade civil são deslegitimados em sua práxis informal e alternativa em relação àquele procedimentalismo institucional autorreferencial, interno e lógico-técnico. Aqui, sobra espaço apenas para o institucionalismo forte, escorado no argumento do anonimato e da espontaneidade do funcionamento de cada instituição, assim como da espontaneidade da evolução social de um modo mais geral.

Ora, essas três assunções teórico-políticas fundamentais do liberalismo político e da social-democracia - novamente: (a) sistemas sociais lógico-técnicos, não-políticos e nãonormativos, de dinâmica interna, autorreferencial e auto-subsistente; (b) anonimato e individualização dos sujeitos políticos, que já não podem mais ser entendidos como classes sociais enquanto sujeitos epistemológico-políticos superdimensionados; e (c) um procedimentalismo imparcial, neutro, formal e impessoal como dinâmica fundamental de legitimação institucional e da relação entre instituições e sociedade civil - incapacitam uma teoria social crítica e sua consequente práxis política tanto de diagnosticarem políticonormativamente a estruturação e o funcionamento das instituições ou sistemas sociais quanto de localizarem e especificarem os sujeitos epistemológico-políticos enquanto classes sociais que efetivamente lutam por hegemonia social-política-institucional. É nesse sentido em que falamos que o anonimato e a espontaneidade dos processos de constituição institucional e de evolução social acabam sendo uma consequência daquelas teorias sociais e políticas, porque elas já não têm em vista, como foco central de sua análise e práxis, a tematização dos sujeitos epistemológico-políticos presentes na Realpolitik, a tematização-legitimação dos sujeitos epistemológico-políticos da práxis e como práxis.

Um exemplo contundente disso pode ser percebido na compreensão de globalização econômica por parte da nova esquerda. A globalização econômica, em verdade, pelo menos na versão que dela dão o liberalismo político e a social-democracia, parece ter assumido em cheio essa impessoalidade, neutralidade, imparcialidade, formalismo, neutralidade e espontaneidade geradas pela correlação e mútua dependência entre instituições lógico-técnicas, autorreferenciais e auto-subsistentes, procedimentalismo impessoal e político e anonimato e individualização dos sujeitos epistemológico-políticos. Com efeito, quando observamos os escritos de Jürgen Habermas e de Anthony Giddens sobre globalização e crise do Estadonação, vemos uma constante totalmente problemática em suas interpretações, posicionamentos e proposições, a saber: a ideia de que o hoje capitalismo internacionalizado-mundializado é caracterizado-dinamizado por capitais transnacionais que não apenas não possuem fronteiras e limitação, senão que também não possuem raízes nacionais e políticas etc., como se fossem capitais sem sujeito e sem contexto, sem vínculos e sem raízes. Nesse sentido, seriam capitais transnacionais de caráter anônimo e impessoal (cf.: Habermas, 2002a, p. 190; 2000, p. 76; Giddens, 1996, p. 95, p. 175). Qual a consequência disso? A consequência que consideramos mais impactante consiste em que, por causa desse anonimato e dessa impessoalidade desses capitais transnacionais, pelo fato de não possuírem raízes em um país específico e nem serem dinamizados-geridos por sujeitos epistemológico-políticos específicos, localizados e 
encarnados, todos os países são igualmente afetados pela atuação e pelas pressões desses capitais transnacionais (tanto especulativos quanto produtivos), de modo que todos os países estariam no mesmo barco, todos eles como vítimas no mesmo grau daqueles capitais impessoais, anônimos e sem raízes. Quer dizer, aqui, perdeu-se totalmente do foco de análise a correlação centros e periferias, a imbricação e mútua dependência entre desenvolvimento e subdesenvolvimento, bem como a herança colonial que está por trás desse tipo de globalização enquanto trasnacionalização do capital e da exploração do trabalho, porque se perdeu a ligação desses capitais e dessas dinâmicas econômicas com sujeitos epistemológico-políticos da práxis e como classes sociais. Nesse sentido, como vimos propondo, a recuperação das noções de sociedade enquanto totalidade normativo-política, de instituição enquanto práxis políticonormativa, de sujeito epistemológico-político enquanto classe social, enquanto macrossujeito epistemológico-político, bem como de lutas de classe enquanto práxis basilar para a constituição institucional e para a dinamização da evolução social, permitem superar o anonimato e individualização dos sujeitos políticos, o procedimentalismo imparcial, neutro, formal e impessoal enquanto arena-dinâmica de constituição, funcionamento e legitimação institucional e, por fim, a noção de sistemas sociais lógico-técnicos, autorreferenciais, autosubsistentes, autônomos, anônimos, impessoais e sobrepostos em relação às classes sociais e suas lutas, em relação à politicidade-carnalidade-normatividade da práxis e de seus sujeitos epistemológico-políticos.

\section{A PRÁXIS COMO O LUGAR DA CRÍTICA E O SUJEITO POLÍTICO DA PRÁXIS COMO O SUJEITO DA TRANSFORMAÇÃO SOCIAL-INSTITUCIONAL}

As nossas considerações precedentes apontam exatamente para a intrínseca correlação entre epistemologia e política, entre criticismo social como práxis política, de modo que haveria essa mútua dependência e ligação, já enfatizada como ponto fundamental da transformação social do e pelo marxismo, entre teoria e prática, entre o teorizar da política e o politizar da teoria. No âmbito das ciências humanas e sociais, na esfera da Realpolitik, que é efetivamente o campo das ciências humanas e sociais, essa ligação umbilical é quem determina o sentido da crítica social e o alcance da práxis política. Dito de outro modo, fazemos teoria da vida cotidiana, sobre ela e a partir dela, de suas lutas, dinâmicas e sujeitos epistemológico-políticos; em verdade, fazemos teoria desde a participação política, como sujeitos epistemológico-políticos engajados que interpretam, questionam e agem na sociedade e frente aos demais sujeitos epistemológico-políticos. Nesse sentido, em primeiro lugar e fundamentalmente, a crítica social é práxis política, posto que parte e emerge do cotidiano da Realpolitik e objetiva seu enquadramento e transformação, da mesma forma como, em segundo lugar e ainda fundamentalmente, esse mesmo criticismo social como práxis política é realizado-dinamizado por sujeitos epistemológico-políticos encarnados-politizados, que interpretam (epistemologia) e agem (política) desde o dia a dia dessa Realpolitik junto a outros sujeitos epistemológico-políticos. Ora, o fato social básico do qual o criticismo social como práxis política parte consiste exatamente na percepção de que a sociedade é construída, legitimada e dinamizada a partir da ação cotidiana em termos de Realpolitik, ação essa que, marcada pela interação e pelo conflito entre sujeitos epistemológico-políticos múltiplos em termos da imposição de suas interpretações de mundo uns frente aos outros e em relação às instituições sociopolíticas e mesmo à noção hegemônica de normatividade social vinculante em uma dada sociedade, é intencional e encarnada, consciente e querente, portanto totalmente politizada e normativa. Ela não é anônima, impessoal e lógico-técnica, senão que exatamente político-normativa, encarnada, intencional, como vimos dizendo.

Por isso, é extremamente importante ao criticismo social como práxis política ou à práxis política como criticismo social a ênfase na práxis e nos sujeitos epistemológicopolíticos constituintes de uma dada sociedade e mais além, com suas posições epistemológicopolíticas e lutas conseqüentes. Isso também significa que é extremamente importante a consideração das instituições sociopolíticas como práxis político-normativa, a partir da recusa, 
seja no primeiro caso, seja no segundo, tanto do sentido lógico-técnico, auto-subsistente e autorreferencial delas e da afirmação de sua dinâmica de constituição e de funcionamento como procedimentalismo imparcial, neutro, formal e impessoal quanto do entendimentofundamentação dos sujeitos epistemológico-políticos como anônimos e individualizados. Conforme pensamos, a individualização e o anonimato dos sujeitos epistemológico-políticos, a compreensão lógico-técnica, autorreferencial e auto-subsistente das instituições ou sistemas sociais e, por fim, a práxis político-institucional como procedimentalismo imparcial, neutro, formal e impessoal representam o fim da participação política ampliada e direta dos sujeitos epistemológico-políticos da sociedade civil frente a si mesmos e frente às instituições, na medida em que essas mesmas instituições lógico-técnicas, por meio de uma dinâmica de funcionamento e de legitimação não-política e não-normativa (que, a nosso ver, é a conseqüência daquele procedimentalismo jurídico-político imparcial, neutro, formal e impessoal), tornam-se sobrepostas e autônomas em relação à práxis política como crítica social e participação política ampliada, baseadas em argumentos normativos, no entendimento normativo das instituições e dos sujeitos epistemológico-políticos.

Nessa correlação entre (a) instituições lógico-técnicas, autorreferenciais e autosubsistentes, (b) procedimentalismo institucional imparcial, neutro, formal e impessoal e (c) individualização e anonimato dos sujeitos epistemológico-políticos desaparece a imbricação entre criticismo social e práxis política, posto que os sistemas sociais ou instituições modernos e os sujeitos epistemológico-políticos são grandemente despolitizados e tecnicizados no primeiro caso, e reduzidos ao individualismo metodológico egoísta e apolítico e incapaz de interpretação-ação epistemológico-política estrutural, no segundo. Com isso, a práxis normativo-política, que a rigor estaria situada na sociedade civil e sob a forma de lutas de classe entre classes sociais ou sujeitos epistemológico-políticos superdimensionados em conflito por hegemonia epistemológico-política, é centralizada, monopolizada e dinamizada pelas próprias instituições autorreferenciais e auto-subsistentes, assumindo um sentido lógicotécnico que, como vimos dizendo, é não-político e não-normativo. Aqui, emerge e se consolida uma forma conservadora de se pensar-fundamentar tanto a constituição-legitimação-evolução institucional internamente a si mesma quanto suas relações com a esfera política representada pela sociedade civil e em particular sua ligação com classes sociais e suas lutas que é altamente institucionalista, que na verdade instaura uma forma de institucionalismo forte em que instituições lógico-técnicas de procedimentalismo basicamente interno, como se fossem sujeitos-estruturas puras, não-políticas e não-normativas, assumem a guarda da normatividade social e o papel epistemológico-político basilar tanto em termos de constituição interna quanto no que se refere à condução da evolução social, minimizando e, em última instância, anulando os sujeitos epistemológico-políticos da sociedade civil e suas lutas, assim como a arena normativo-política representada pela sociedade civil - aqui, repetimos novamente, instituições lógico-técnicas, autorreferenciais e auto-subsistentes, de procedimentalismo apolítico interno, tornam-se independentes, sobrepostas e despolitizadas em relação às classes sociais, às lutas de classe e à sociedade civil. Essa forma teórico-política conservadora de se conceber as instituições, os sujeitos epistemológico-políticos e a própria política, marcada pelo institucionalismo forte, pela apoliticidade e tecnicalidade do procedimentalismo institucional e pela tecnocracia política, se reflete na afirmação da não-politicidade, não-carnalidade e nãonormatividade dos sistemas sociais, assim como na recusa, por parte do conservadorismo, em afirmar uma práxis político-normativa ampliada, direta e inclusiva em relação à dinâmica institucional autorreferencial e auto-subsistente e frente aos técnicos e às elites institucionais (partidos políticos, oligarquias econômicas, tecnocracia etc.). Esta é a razão porque tanto a teoria de sistemas utilizada por teorias sociais críticas contemporâneas (como é o caso de Habermas e Giddens) quanto o procedimentalismo jurídico-político imparcial, neutro, formal e impessoal utilizado por teorias políticas liberais hodiernas (Rawls e Habermas, por exemplo) simplesmente não conseguem dar conta de correlacionar criticismo social e práxis política radical - eles que efetivamente intentam fundamentar-construir um modelo de crítica social e de práxis política radical para as sociedades democráticas complexas contemporâneas.

Essa correlação entre crítica social e práxis política somente é possível quando 
abandonamos seja a compreensão lógico-técnica de sistemas sociais autorreferenciais e autosubsistentes, seja o procedimentalismo imparcial, neutro, formal e impessoal como base da legitimação-funcionamento-administração das instituições ou sistemas sociais e, por fim, como complemento, o anonimato e a individualização dos sujeitos epistemológico-políticos. Essa correlação entre crítica social e práxis política, por conseguinte, somente é possível efetivamente de ser sustentada, legitimada e aplicada quando politizamos completamente as instituições e os sujeitos epistemológico-políticos, localizando-os dentro do contexto políticonormativo representado pela sociedade civil e dinamizado pelas classes sociais e por suas lutas por hegemonia. Isso significa, em primeiro lugar, a recusa de uma posição epistemológicopolítica fundamental própria à teoria política contemporânea, especialmente de índole liberal e social-democrata, e tanto à direita (Hayek, Friedman, Nozick) quanto à esquerda (Rawls, Habermas e Giddens), a saber, a centralidade do institucionalismo como objeto e sujeito da práxis política, um forma de entendimento do institucionalismo - esta como objeto das teorias da justiça e sujeito-arena da dinâmica política democrática - que é construída a partir da correlação entre teoria de sistemas e procedimentalismo jurídico-político. No caso da teoria de sistemas, como vimos dizendo, está a ideia de que as instituições sociopolíticas possuem uma constituição que é, sim, normativo-política, mas que também é, no mesmo diapasão, lógicotécnica, no sentido de que ela possui constituição, dinâmica e legitimação internas que somente são entendidas, constituídas e orientadas desde dentro, por meio de um trabalho técnico, objetivo - no sentido de neutro e impessoal - referentemente às classes sociais e suas lutas políticas (cf.: Habermas, 2012a, p. 588-591; 2012b, p. 275-288, p. 365; 1997, p. 163; Giddens, 2000, p. 109-110; 2001, p. 123-134). Aqui, aparece o procedimentalismo jurídicopolítico enquanto dinâmica de constituição, legitimação e evolução institucional que é imparcial, neutra, formal e impessoal frente às classes sociais e suas lutas: somente ele faz jus seja à individualização e ao anonimato dos sujeitos epistemológico-políticos, seja ao sentido sistêmico das instituições. Por causa de ambos os pontos, tem-se o institucionalismo como objeto das teorias da justiça e sujeito-arena da Realpolitik, para além dos - e ignorando teórica e politicamente os - sujeitos epistemológico-políticos da sociedade civil e suas lutas por hegemonia, que seriam secundários e periféricos em relação a esse mesmo institucionalismo (cf.: Rawls, 2000a, §§ 1-2, p. 03-12, § 4, p. 19-24; 2000b, p. 01-42; 2003, § 4, p. 13-17, §§ 2323-25, p. 113-125; Habermas, 2003a, p. 20, p. 61; 2003b, p. 21-23).

Ora, o institucionalismo, e um tipo de institucionalismo forte e apolítico, como consequência das teorias liberais e social-democratas contemporâneas, é justificado por um triplo e imbricado modo de análise do processo de constituição e de evolução da modernização ocidental: (a) a compreensão da modernização ocidental como emergência e consolidação de sistemas sociais ou instituições lógico-técnicos, não-políticos e não-normativos, de procedimentalismo basicamente interno e instrumental, autorreferenciais, auto-subsistentes, autônomas e sobrepostas em relação às classes sociais e suas lutas político-normativas, como se esses sistemas sociais fossem sujeitos-estruturas puras, apenas lógico-técnicas e acessíveis por um tipo de cientificismo apolítico, imparcial, neutro, formal e impessoal assumido por técnicos e elites institucionais; (b) a afirmação do anonimato e da individualização dos sujeitos políticos, que, por não serem mais constituídos e dinamizados como macrossujeitos, como sujeitos epistemológico-políticos superdimensionados, já não conseguiriam mais agir como corpo coletivo e em sentido estrutural, de modo a influenciar-modificar dinâmicas sócioinstitucionais de nível macro, o que significa que essas dinâmicas sócio-institucionais de nível estrutural e com alcance macro, se são possíveis, o são exatamente por causa das instituições sociopolíticas, e não por causa das classes sociais como super-sujeitos epistemológicopolíticos da práxis; (c) um conceito de normatividade social, se é possível de ser construído e dinamizado social e institucionalmente, o é a partir das instituições como centralizadoras, guardadoras e dinamizadoras dessa mesma normatividade social, o que significa que a constituição, legitimação e fomento de uma noção vinculante de normatividade social passa a ser uma função-ação institucional, de modo que, em um poderoso sentido, essa mesma normatividade social - enquanto concepção epistemológico-política hegemônica em dado contexto sócio-institucional - torna-se sobreposta e independente tanto dos sujeitos 
epistemológico-políticos quanto de suas lutas por hegemonia em termos de sociedade civil e dali para as instituições, e vice-versa.

Vamos refletir mais um pouco sobre essa forma de institucionalismo direta ou indiretamente desenvolvida e legitimada pelas teorias políticas liberais e social-democratas contemporâneas. No momento em que a sociedade já não se constitui mais como totalidade político-normativa, mas sim por sistemas sociais lógico-técnicos privados, autorreferenciais e auto-subsistentes, instituições ou sistemas sociais particularizados, se por um lado ainda potencializam e dinamizam conseqüências estruturais, por outro já não podem ser enquadrados política e normativamente por suas conseqüências totalizantes - eles determinam configurações sociais e status quo, é verdade, mas não de modo férreo e muito menos de modo político (senão que a partir de fatores e de movimentos técnicos), posto que cada sistema social (pensemos no Estado burocrático-administrativo e no mercado capitalista, que são os dois sistemas sociais básicos da modernização ocidental) centraliza e monopoliza (e despolitiza) um campo específico da vida social, e não todos os campos, de modo que sua atuação é localizada, pontual, não-totalizante. Logo, não existe politização total, assim como não é possível uma práxis política total, isto é, que politize tudo e que incida sobre todos os pontos da sociedade. Aqui, existem certos campos, práticas e sujeitos epistemológico-políticos que não são políticos e nem agem politicamente. Esse é o caso, como vimos dizendo, da concepção lógico-técnica dos sistemas sociais, que pressupõe que eles não são práxis e sujeitos epistemológico-políticos, mas sim fundamentalmente estruturas-sujeitos instrumentais, lógico-técnicos, não-políticos e não-normativos que, por serem autorreferenciais e auto-subsistentes, também são particularizados em relação ao resto da sociedade e, com isso, possuindo conseqüências relativas apenas ao seu próprio entorno, ao seu contexto muito específico. Nesse sentido, o ativismo e a transformação políticas são possíveis, mas já não possuem incidência macroestrutural, já não podem politizar tudo e querer transformar tudo por meio da própria práxis política, enquanto práxis política, como sujeitos epistemológico-políticos. Certas estruturas, práticas e sujeitos sócio-institucionais não são estruturas, práticas e sujeitos normativo-políticos, senão que apenas lógico-técnicos, e é desse modo - lógico-técnico, não-político e não-normativo - que devem ser entendidos e enquadrados. É por isso que, nessas teorias políticas liberais e social-democratas, a política é um sistema social entre outros, não o centro da sociedade-práxis e nem a maior instituição social, o que também significa que ela está lado a lado e em competição com estes outros sistemas e certamente restringida por eles, conforme insiste Habermas com veemência em seu Direito e Democracia: entre Facticidade e Validade (cf.: Habermas, 2003b, p. 25; 2002b, p. 501). Existem várias formas de poder sócio-institucional, cada um dotado de sua legitimidade, e a política é somente mais um, quando pensamos na constituição e na evolução das sociedades complexas contemporâneas, de modernização ocidental. Esta especificidade, ensinada-desenvolvida pela teoria de sistemas, não pode ser esquecida pelos sujeitos epistemológico-políticos em termos de criticismo social e de práxis política.

Da mesma forma, no momento em que existem sistemas sociais lógico-técnicos, instrumentais, de dinâmica basicamente interna, autorreferencial e auto-subsistente, e com funcionamento, constituição e legitimação não-políticos e não-normativos, esses mesmos sistemas sociais tornam-se, em grande medida, despolitizados, enquanto estruturas-sujeitos técnicos acessíveis por meio de técnica de administração e de gerenciamento, objetivamente neutra e metodologicamente guiada, lógica, sem qualquer possibilidade - ou com pouca possibilidade - de politização e de espontaneidade. Com isso, o ponto arquimédico para avaliação, enquadramento e administração de sistemas sociais ou instituições particularizadas, autorreferenciais, não-políticas e não-normativas é constituído pela sua própria dinâmica lógico-técnica de funcionamento e de legitimação e de constituição, que é interna ao próprio sistema social e assumida por seus técnicos e elites internos. Da mesma forma, e como condição para isso, o fato de um sistema social ser auto-subsistente significa que suas condições de funcionamento, de programação e de legitimação são internas a ele mesmo, como vimos dizendo, o que implica em que somente se acessa-entende-transforma um sistema social desde dentro, desde seus próprios meios lógico-técnicos e por seu próprio pessoal 
interno, pelo seu staff autorizado, legitimado pelo sistema social em questão. Desse modo, um sistema social lógico-técnico, autorreferencial e auto-subsistente não apenas torna-se despolitizado e sobreposto relativamente à práxis política como luta social e autônomo em relação às classes sociais como sujeitos epistemológico-políticos, senão que constitui-se no seu próprio paradigma para constituição, legitimação e evolução internas, eliminando de si mesmo qualquer politicidade-carnalidade, qualquer resquício de sujeito epistemológico-político e de contato com a sociedade civil, com a práxis de um modo mais geral. Aqui, a práxis política é negada e, na verdade, transformada em procedimentalismo institucional lógico-técnico, imparcial, neutro, formal e impessoal exatamente por causa do fato de que o sistema social autorreferencial e auto-subsistente é o sujeito por excelência de sua própria constituiçãolegitimação-transformação. A política como normatividade já não seria mais o critérioparadigma a partir do qual os sistemas sociais, tanto em sua constituição-legitimaçãofuncionamento interno quanto em termos de sua relação com o entorno sociopolítico mais geral, seriam avaliados, enquadrados e orientados, pelo menos não em todos os casos. De todo modo, quem definiria em quais casos poder-se-ia pensar-enquadrar-orientar política e normativamente esses mesmos sistemas sociais, seu funcionamento e sua legitimação, assim como suas relações? Ora, os próprios sistemas sociais, por seus técnicos e desde uma perspectiva lógico-técnica, desde um decisionismo lógico-técnico!

Por fim, no momento em que não existem mais classes sociais como sujeitos epistemológico-políticos superdimensionados da transformação social e da configuração institucional, neste momento, portanto, em que as sociedades democráticas complexas contemporâneas são marcadas pelos consolidados anonimato e individualização dos sujeitos epistemológico-políticos da práxis, incapazes de uma ação estrutural regida-dinamizada por consciência de classe, o que sobra são as instituições de um modo geral e as instituições jurídico-políticas em particular como a base da constituição, da legitimação e da evolução tanto da sociedade em geral quanto da esfera público-política em particular. É aqui, e como conseqüência também dos dois pontos acima desenvolvidos, que podemos situar a ideia de que o institucionalismo é, nas teorias políticas liberais e social-democratas contemporâneas, o objeto da teoria da justiça e o sujeito-arena político da Realpolitik. Com efeito, o primeiro ponto de chama a atenção consiste exatamente na substituição, em termos de tematizaçãoentendimento da modernização ocidental, das classes sociais, dos sujeitos epistemológicopolíticos, pelos próprios sistemas ou instituições sociais modernos. De fato, o grosso das teorias sociológicas contemporâneas - nós citaríamos, aqui, Parsons, Luhmann, Habermas e Giddens - já não utiliza mais, como chave-de-leitura epistemológico-política a tematização da práxis e dos sujeitos epistemológico-políticos como classes sociais em termos de compreensão e de enquadramento desse processo de modernização ocidental, dando ênfase central, em termos teórico-políticos, àquelas instituições ou sistemas sociais lógico-técnicos, autorreferenciais e auto-subsistentes de que falamos acima (cf.: Parsons, 1991, 2010a, 2010b; Luhmann, 2006; Habermas, 2012a, 2012b, 2002b, 2003a, 2003b; Giddens, 1996, 2000, 2001). Eles efetivamente dinamizariam seja sua própria esfera interna, seja a evolução social de um modo mais geral, permitindo o diagnóstico sociológico e o ativismo político, ainda que não mais em um sentido radical, direto, dada aquela constituição lógico-técnica, autorreferencial e auto-subsistente dos sistemas sociais modernos. As instituições são o objeto das teorias da justiça por esse fato óbvio, isto é, porque elas gerariam efeitos estruturais mínimos, objetivos que, por sua vez, dinamizariam a consolidação do status quo e a dinâmica da evolução social. No mesmo diapasão, o abandono da tematização-utilização da noção de sujeito epistemológico-político como classe social como base para o entendimento-enquadramentoorientação do processo de modernização ocidental tanto em termos institucionais quanto em termos de sociedade civil e como práxis política, na medida em que tais sujeitos já não representariam mais atores superdimensionados da evolução societal-institucional (ao passo que as instituições seriam, sim, arenas-sujeitos de ação estrutural), esse abandono aponta exatamente para o fato de que o institucionalismo também é o sujeito da evolução sociopolítica, posto que o procedimentalismo institucional dinamizado a partir de regras, práticas, valores e sujeitos neutros, formais, imparciais e impessoais - e somente esse 
procedimentalismo sistêmico-institucional neutro e formal e esse tipo de sujeito epistemológico-político impessoal e imparcial institucionalizado - faria jus de modo efetivo à e representaria de modo competente a pluralidade de sujeitos anônimos e individualizados da sociedade civil, sem prejuízo ou favorecimento de alguém em particular (cf.: Rawls, 2000c, 2003; Habermas, 2003a, 2003b; Forst, 2010).

Dito de outro modo, a noção de classe social partia do pressuposto de que haveria sujeitos epistemológico-políticos especiais em termos de crítica e transformação sócioinstitucionais. Haveria, por outras palavras, um sujeito epistemológico-político críticoemancipatório que, por isso mesmo, teria a missão de enquadrar-criticar-transformar as instituições e, ao cabo, a própria sociedade como um todo. Porém, no momento em que já não existe mais essa noção de classe social como super-sujeito político, no momento, portanto, em que tem-se um anonimato e uma individualização consolidados dos sujeitos epistemológicopolíticos, nenhum sujeito epistemológico-político particular pode assumir aquele sentido messiânico, crítico-emancipatório que o conceito de classe social como sujeito epistemológico-político superdimensionado e estrutural havia centralizado e monopolizado. Não existe o sujeito epistemológico-político da salvação social-institucional, não existe um sujeito epistemológico-político messiânico dessa mesma evolução social-institucional. Doravante, a evolução social-institucional é representativo-participativa e baseada no reformismo político guiado, centralizado e dinamizado pelas instituições jurídico-políticas. Ora, como única forma de adequação a este fato básico da vida sociocultural e institucional contemporânea, a saber, o anonimato e a individualização dos sujeitos epistemológicopolíticos (cf.: Habermas, 2003a, p. 83; 2003b, p. 72; Giddens, 2000, p. 38-43; 2001, p. 144154), como única forma, ainda, de adequação ao fato do pluralismo axiológico-normativo (cf.: Rawls, 2000c, p. 180-220; Habermas, 2002a, p. 19-41; 2003b, p. 24-25; Forst, 2010, p. 334345), estas instituições jurídico-políticas democráticas necessitam assumir como sua basedinâmica de constituição-legitimação-evolução interna e como ponte frente à sociedade civil e seus sujeitos epistemológico-políticos particulares, um procedimentalismo institucional que é neutro, imparcial, formal e impessoal relativamente às classes sociais e às lutas de classe. Ora, o procedimentalismo jurídico-político, ao assumir estes qualificativos-características de imparcial, neutro, formal e impessoal significa e implica em uma dinâmica de funcionamento, de constituição, de legitimação e de evolução que adquire contornos apolíticos, não-políticos e não-normativos, como a forma epistemológico-política mais adequada para a igual representação de todos os sujeitos sociais. Nesse sentido, o caminho programático-político assumido, desenvolvido e representado pelas instituições sob a forma desse procedimentalismo jurídico-político impessoal, imparcial, neutro e formal é, como vimos dizendo, um caminho apolítico e despolitizador, que pressupõe que uma arena e um ponto de partida não-políticos, assumidos por sujeitos que deixam de lado sua politicidade e sua vinculação político-normativa (pense-se, nesse caso, no modelo da posição original e de seu véu da ignorância, conforme tematizado por John Rawls), poderiam efetivamente gerar um paradigma epistemológico-político-normativo institucional para a participação política e a crítica social por parte dos sujeitos epistemológico-políticos da sociedade civil em relação a si mesmos, às instituições jurídico-políticas e aos sistemas sociais, bem como para o ativismo político-normativo das instituições internamente a si mesmas, frente à sociedade civil e seus sujeitos epistemológico-políticos e fazendo o elo entre sistemas sociais e sociedade civil, elo esse, médium esse que seria constituído-dinamizado pelas próprias instituições jurídicopolíticas e como procedimentalismo imparcial, neutro, formal e impessoal.

Note-se o argumento central que justifica o procedimentalismo jurídico-político imparcial, neutro, formal e impessoal como base para o criticismo social e a participação política, como base ainda para a correlação entre sociedade civil e sistemas sociais, nas sociedades democráticas complexas contemporâneas, de modernização burocrático-capitalista: somente um ponto de partida não-político institucionalizado, sustentado e realizado desde as instituições, permite a construção de uma noção objetiva, universal e vinculante de normatividade social que, depois, será utilizada pelas instituições e pelos sujeitos epistemológico-políticos como base de suas lutas, de seu criticismo e de suas reivindicações. 
Novamente: um ponto de partida e um procedimento institucional apolíticos são condições epistemológico-políticas fundamentais, são estratégias programático-propositivas fundamentais para fundar-se um ponto de vista político tanto em termos institucionais quanto em termos de práxis! No mesmo sentido, apenas sujeitos epistemológico-políticos neutros e despolitizados, apolíticos e cegos politicamente em seu sentido mais pleno e pungente, conforme pressuposto-assunção-mote pelas-das teorias do contrato social sob a forma de procedimentalismo neutro, formal, imparcial e impessoal, teriam condições de fundar uma práxis político-normativa que oferece um paradigma crítico-emancipatório para o criticismo social como práxis política! Com isso, as classes sociais e as lutas de classe não apenas passam para segundo plano em termos de construção desse paradigma político-normativo institucional, senão que são apagadas seja dessa construção paradigmática, seja, mais ainda, da própria compreensão-gênese do processo de modernização ocidental, de sua dinâmica evolutiva e da constituição-dinamização de seus sistemas sociais, como se eles fossem processos e estruturas sem sujeitos epistemológico-políticos, sem politicidade, carnalidade e normatividade. Aqui, um paradigma político sem política, dinamizado por instituições jurídico-políticas técnicas e realizado-sustentado por sujeitos epistemológico-políticos apolíticos descamba para a imparcialidade, neutralidade, formalidade e impessoalidade como os critérios normativo-programáticos basilares para a realização da crítica social, da participação política e da atuação das instituições. Assim, correlatamente, tem-se a minimização do alcance e do sentido da crítica social, a grande despolitização e a sensível perda de intensidade da participação política frente às instituições e, finalmente, mas não menos importante, a sobreposição e autonomização das instituições jurídico-políticas em particular e dos sistemas sociais em geral frente à práxis política como criticismo social e politização ampliados dos movimentos sociais e das iniciativas cidadãs relativamente aos sistemas sociais lógico-técnicos, que seguem mantendo praticamente inquestionado e intocado seu sentido lógico-técnico, autorreferencial e auto-subsistente, gerando o institucionalismo forte - centralização e monopolização da constituição-legitimação-evolução das instituições pelas próprias instituições e seus técnicos, desde uma perspectiva não-política, não-normativa e lógico-técnica que é autorreferencial e auto-subsistente, autônoma e sobreposta em relação à sociedade civil, às classes sociais e às lutas de classe.

Da correlação entre instituições lógico-técnicas, autorreferenciais e auto-subsistentes, com um procedimentalismo imparcial, neutro, formal e impessoal como base do funcionamento-legitimação das instituições e como forma paradigmática de orientação normativa das lutas sociais e dos sujeitos epistemológico-políticas, tem-se a centralidade do institucionalismo, conforme vimos argumentando, e de um institucionalismo forte que concebe exatamente as instituições como objeto da teoria da justiça e sujeitos da práxis política. Ora, esse institucionalismo, na medida em que tecniciza e despolitiza os sistemas sociais, tornando-os fechados, autônomos e sobrepostos em relação às classes sociais e às suas lutas, e na medida em que afirma-exige um procedimentalismo apolítico e sem sujeito, gera alguns problemas fundamentais para a realização do criticismo social como práxis política: primeiramente, o institucionalismo acaba sendo efetivamente o sujeito epistemológico-político central, para além dos sujeitos epistemológico-políticos da sociedade civil, minimizando-os e, em verdade, submetendo-os à dinâmica de funcionamento e de legitimação assumida, centralizada e dinamizada pelas elites institucionais, tais como os técnicos dos sistemas sociais e os partidos políticos; esse mesmo institucionalismo, com base em uma dinâmica autorreferencial, auto-subsistente e lógico-técnica que é interna às próprias instituições, tornase também a base paradigmática, normativa - apolítica, despolitizadora - para 0 enquadramento-legitimação-validação dos sujeitos epistemológico-políticos nãoinstitucionalizados e das lutas sociais, o que significa dizer-se que o criticismo social como práxis política, realizado desde a sociedade civil por sujeitos epistemológico-políticos nãoinstitucionalizados, é enquadrado pelas e dependente das elites-técnicos institucionais, devendo assumir uma correlação estreita com o institucionalismo e, mais ainda, sendo canalizado por este, guiado por este - assim, as lutas sociais e os sujeitos epistemológicopolíticos informais, não-institucionalizados, podem alcançar no máximo as escadas das 
instituições, mas a palavra final, o decisionismo final é dado desde a dinâmica lógico-técnica, imparcial, impessoal institucional e pela atuação das elites-técnicos institucionais; por fim, o institucionalismo torna-se o médium que liga os sistemas sociais lógico-técnicos e os sujeitos epistemológico-políticos não-institucionalizados e suas lutas desde a sociedade civil, de modo que o criticismo social como práxis política, dirigido aos sistemas sociais autorreferenciais, auto-subsistentes e lógico-técnicos com vistas à sua politização, acaba sendo freado e minado pelo institucionalismo, de modo que o institucionalismo acaba assumindo essa função de crítica social e de transformação política, legitimando ou deslegitimando qualquer forma de práxis política e de sujeito epistemológico-político. Aqui, o institucionalismo torna-se a arena, o procedimentalismo e o sujeito de sua própria constituição, legitimação e evolução ao longo do tempo, ligando os demais sistemas sociais e a sociedade civil, as elites institucionais e os sujeitos epistemológico-políticos não-institucionalizados, mas de um modo tal que a institucionalização é o ponto de partida, a dinâmica e o ponto de chegada de qualquer práxis crítico-emancipatória. Desse modo, sem institucionalização, não haveria crítica social e práxis política, pelo menos não em seu sentido efetivo, transformador, legitimado (cf.: Habermas, 2003 b, p. 22-23; Rawls, 2000a, § 53, p. 388-395). E sem o ativismo institucional e como ativismo institucional não haveria sujeito epistemológico-político efetivo e legítimo para a construção-dinamização institucional e transformação social (cf.: Habermas, 2003b, p. 104106).

O tipo de institucionalismo surgido a partir da correlação entre (a) a compreensão lógico-técnica, não-política e não-normativa dos sistemas sociais modernos, (b) a noção de modernização ocidental como auto-diferenciação, autorreferencialidade, auto-subsistência e autonomia de sistemas sociais lógico-técnicos frente à práxis política, à normatividade social, às classes sociais e suas lutas, e (c) o procedimentalismo jurídico-político imparcial, neutro, formal e impessoal como base da constituição-legitimação-evolução das instituições de um modo geral e das instituições jurídico-políticas em particular, assim como, evidentemente, como base normativa para a orientação do criticismo social como práxis política, da participação política de movimentos sociais e de iniciativas cidadãs frente às instituições, esse institucionalismo dali surgido caracteriza-se pelo fato de ser sem politicidade, carnalidade e normatividade. É uma forma de institucionalismo que aponta para o fato de que os sistemas sociais são estruturas-sujeitos puramente técnicos, instrumentais, ou basicamente técnicos e instrumentais, em que a técnica fria e objetiva, definível e mensurável cientificamente, define a constituição-legitimação-evolução institucional e a relação das instituições com a sociedade civil. Obviamente, as teorias sociais críticas e as filosofias políticas liberais que usam a teoria de sistemas e o procedimentalismo jurídico-político apolítico como fundamento para o criticismo social como práxis política tentam conciliar teoria de sistemas (instituições lógicotécnicas autorreferenciais e auto-subsistentes) com normatividade social (a sociedade civil como substrato cultural-normativo e epistemológico-político das instituições), de modo que, se por um lado as instituições teriam essa estruturação e esse funcionamento lógico-técnicos, por outro elas também dependeriam - e dependeriam fundamentalmente - seja da participação política, seja do substrato normativo que somente seria dado pela participação social permanente, pelo criticismo social tornado prática corriqueira por movimentos sociais e por iniciativas cidadãs em termos de sociedade civil e sob a forma de esfera público-política, o que significa dizer que, nessas teorias sociais críticas e filosofias políticas liberais e socialdemocratas (as já citadas acima), a correlação entre institucionalização e espontaneidade, política formal e política informal, sujeitos epistemológico-políticos institucionalizados e sujeitos epistemológico-políticos não-institucionalizados, instituições e sociedade civil, procedimentalismo institucional interno e esfera público-política, é que permitiria o controle e a reorientação das instituições, de modo a evitar-se uma sua tecnicização e despolitização estritas e seu consequente institucionalismo forte e apolítico (cf.: Rawls, 2000a, § 53, p. 388395; Habermas, 2003a, p. 25; 2003b, p. 24, p. 104-106; Giddens, 2000, p. 47-48). Entretanto, como vimos dizendo, a correlação de teoria de sistemas (instituições lógico-técnicas autorreferenciais e auto-subsistentes, de funcionamento e dinâmica internos) e de procedimentalismo institucional (institucionalização como procedimentalismo imparcial, 
neutro, formal e impessoal) leva a que a sociedade civil como arena político-normativa e os sujeitos epistemológico-políticos não-institucionalizados como classes sociais sejam colocados em segundo plano pela centralidade do institucionalismo como objeto das teorias da justiça e como sujeito da práxis política. Aqui, a práxis política democrática primeiro está limitada pelo sentido lógico-técnico, autorreferencial, auto-subsistente, autônomo e fechado das instituições em relação a uma politização direta, abrangente e inclusiva, o que significa, conforme falamos acima, que nem tudo é política e político; segundo, ela está orientada e dinamizada pelo institucionalismo, no sentido de que (a) a institucionalização é o começo, o caminho e o fim do criticismo social como práxis política, (b) os sujeitos epistemológicopolíticos institucionalizados são o sujeito político por excelência da constituição-legitimação institucional e da realização da transformação social, representando e assumindo as pautas e a participação político-normativas dos sujeitos epistemológico-políticos e da práxis política nãoinstitucionalizados, e (c) necessita assumir um sentido e uma dinâmica imparcial, neutra, formal e impessoal relativamente às instituições, de modo que os sujeitos epistemológicopolíticos da sociedade civil têm apagada sua atuação como classe social e como práxis política espontânea. Por fim, (d) a práxis política estaria limitada, orientada e definida pelo institucionalismo e pelas autoridades institucionais no sentido de que a sociedade civil e a esfera público-política seriam secundárias - não obstante representarem, nas teorias sociais críticas e nas filosofias políticas liberais, o núcleo político-normativo das instituições - frente à arena institucional, seja no sentido de que as instituições são lógico-técnicas, de procedimentalismo interno, autorreferencial e auto-subsistente em grande medida, seja no fato de que os sujeitos epistemológico-políticos institucionais por excelência são as elites-técnicos institucionais, e não as classe sociais, seja, por fim, no fato de que a dinâmica institucional é caracterizada por aquele procedimentalismo imparcial, neutro, formal e impessoal apolítico de que vimos falando, e não pelas lutas de classe dinamizadas desde a sociedade civil. De uma só tacada, portanto, a correlação de instituições lógico-técnicas, sistemas sociais autorreferenciais e auto-subsistentes e procedimentalismo apolítico permite a despolitização e a sobreposição institucionais em relação às classes sociais e às lutas de classe, possibilitando também o fechamento e a autonomização dos sistemas sociais em relação à participação social ampliada e inclusiva, à sua politização abrangente por parte dessa participação política ampliada e inclusiva. No mesmo diapasão, e como conseqüência daquela correlação, o criticismo social como práxis política sai das ruas e dos sujeitos epistemológico-políticos não-institucionais e é assumido, centralizado e monopolizado pelas próprias instituições desde essa perspectiva lógico-técnica, autorreferencial, auto-subsistente, autônoma e sobreposta em relação às ruas. Com isso, o institucionalismo torna-se a arena político-programática, o paradigma críticonormativo e o sujeito epistemológico-político de si mesmo, da legitimação e do enquadramento das classes sociais e de suas lutas e, por fim, de qualquer possível relaçãoligação entre sistemas sociais e sociedade civil, elites-técnicos institucionais e sujeitos epistemológico-políticos não-institucionalizados.

Essa forma de institucionalismo também elide, minimiza e apaga, em grande medida, o papel da esfera público-política como lugar da práxis epistemológico-política, ao tornar as instituições em autorreferenciais e auto-subsistentes, como estruturas-sujeitos lógico-técnicos que se autonomizam e se sobrepõem a essa mesma esfera público-política, seus sujeitos epistemológico-políticos e suas lutas sociais. Essa forma de institucionalismo, ainda aqui, solapa a práxis política espontânea e contraposta às instituições constituída e dinamizada pela sociedade civil exatamente por colocar o procedimentalismo imparcial, neutro, formal e impessoal interno às instituições como a arena-práxis seja para a constituição-legitimaçãoevolução institucional, seja para, a partir daqui, pensar-se e problematizar-se a constituiçãoevolução social de um modo mais geral. Em ambos os casos, a esfera público-política, enquanto arena e práxis político-normativa, é enquadrada, periferizada e, ao cabo, substituída pelo institucionalismo lógico-técnico, não-político e não-normativo, com seu procedimentalismo apolítico, sem carnalidade. Nesse sentido, e ainda como consequência, as classes sociais e suas lutas, próprias da esfera público-política, são minimizadas e mesmo deletadas do horizonte do institucionalismo, que se concebe exatamente como uma área- 
estrutura-sujeito puro, imparcial, impessoal, formal e neutro em relação a tais classes e suas lutas por hegemonia. Desse modo, em primeiro lugar, os sujeitos epistemológico-políticos institucionalizados, com base naquele procedimento lógico-técnico objetivo e apolítico, podem decidir em nome de todos e representando todos, para além das classes sociais e de suas lutas. E, em segundo lugar, a esfera do institucionalismo, sua constituição lógico-técnica, sua dinâmica procedural e seus sujeitos epistemológico-políticos neutros e impessoais aparecem sobrepostos e autônomos em relação às classes sociais e suas lutas, com capacidade para assumir - e, assim, prescindir - delas, periferizando-as, suas pautas e sua luta, de forma a negá-las, minimizá-las. Nesse sentido, a correlação entre instituições lógico-técnicas, procedimentalismo apolítico e sujeitos epistemológico-políticos imparciais, neutros e impessoais leva a uma dicotomia entre institucionalismo e esfera público-política que não apenas não pode ser superada - por parte das teorias políticas liberais e seu modelo de procedimentalismo político enquanto correlação entre política formal e política informal - pela afirmação teórico-política desta separação, mas ao mesmo tempo pela inserção-dependência do institucionalismo em relação à sociedade civil, senão que conduz diretamente ao institucionalismo forte próprio do conservadorismo, a saber: de um lado, temos a esfera público-política e a sociedade civil com suas classes sociais e suas lutas por poder e hegemonia; e, de outro, temos a esfera institucional com sua constituição-legitimaçãoevolução lógico-técnica, apolítica, desde um procedimentalismo imparcial, neutro, formal e impessoal administrado e utilizado por técnicos baseados em análise instrumental objetiva. Aqui, nessa dicotomia, a sociedade civil e a esfera público-política, com suas classes sociais antagônicas e suas lutas por poder e hegemonia, apareceriam como uma esfera de caos, anomia e vinculação político-normativa, ao passo que, na esfera dos sistemas sociais ou instituições, a arena, a dinâmica e os sujeitos epistemológico-políticos institucionalizados ou sistêmicos apareceriam como ordenados, objetivos, neutros, impessoais e imparciais, de modo não apenas a representar equitativamente os interesses de todos os sujeitos epistemológicopolíticos da sociedade civil, mas também de canalizar a anomia e a barbárie destes dentro dos trilhos pacíficos e ordeiros - porque lógico-técnicos, imparciais, neutros, formais e impessoais - das próprias instituições e por seus técnicos. A esfera público-política e a sociedade civil, portanto, nessa visão e como conseqüência dela, apareceria como excessivamente política e politizadora, ao passo que o institucionalismo seria caracterizado exatamente pela correlação na dosagem certa, moderada, entre politização e tecnização.

E por isso que estamos enfatizando que uma teoria social crítica como práxis política necessita minar, enfraquecer e deslegitimar a imbricada correlação, própria de teorias políticas contemporâneas, entre teoria de sistemas, procedimentalismo e institucionalismo, isto é, entre (a) uma concepção lógico-técnica das instituições ou sistemas sociais, enquanto estruturassujeitos puros, fundamentalmente instrumentais, temperada com (b) uma noção de modernização ocidental enquanto auto-diferenciação, autorreferencialidade, auto-subsistência e autonomia desses sistemas sociais lógico-técnicos, dinamizados por (c) um procedimentalismo institucional que é imparcial, neutro, formal e impessoal relativamente às classes sociais e suas lutas por poder, que (d) institui um tipo de instituição ou sistema social que é autônomo, fechado e sobreposto em relação à sociedade civil e à esfera público-política, seus sujeitos epistemológico-políticos não-institucionalizados e suas lutas, (e) consolidando uma barreira bastante intransponível entre institucionalismo e espontaneidade, sistemas sociais e sociedade civil, procedimentalismo apolítico e práxis política como luta social, tecnocracia e criticismo social, sujeitos epistemológico-políticos institucionalizados e classes sociais. É necessária, portanto, uma forma de criticismo social como práxis política que, correlatamente, (1) ofereça um modelo político-normativo de modernização ocidental de um modo geral e dos sistemas sociais ou instituições modernos em particular, modelo político-normativo esse que negue o caráter lógico-técnico, autorreferencial e auto-subsistente dessas mesmas instituições; (2) desloque os pesos do institucionalismo para a sociedade civil e para a esfera públicopolítica enquanto esfera-práxis fundamentalmente político-normativa; (3) substitua o procedimentalismo jurídico-político imparcial, neutro, formal e impessoal enquanto arenapráxis institucional e paradigma normativo tanto para a constituição-legitimação-evolução dos 
sistemas sociais e para a relação entre instituições e sociedade civil quanto para a própria realização do criticismo social enquanto práxis política pela noção de lutas de classe enquanto efetivamente caracterizando-dinamizando a práxis política cotidiana; e, finalmente, (4) substitua os sujeitos epistemológico-políticos institucionalizados, de cunho lógico-técnico e apolítico, e baseados naquele procedimentalismo lógico-técnico e apolítico acima especificado, pelas classes sociais enquanto sujeitos epistemológicos-políticos-normativos da constituição institucional e da transformação social que, por meio de suas lutas por hegemonia teórico-política, efetivamente dinamizam e orientam a estruturação das instituições e o caminho da evolução social. Nesse caso, a noção de classe social enquanto macrossujeito epistemológico-político da evolução social-institucional permitiria, concomitante e imbricadamente, a superação do anonimato e da individualização dos sujeitos epistemológicopolíticos assumida e enfatizada por teorias políticas liberais e social-democratas contemporâneas e da tecnicização e da apoliticidade do procedimentalismo institucional de auto-constituição, auto-fundamentação e auto-evolução. Com isso, o criticismo social como práxis política faria voltar às ruas e sob a forma de lutas sociais entre sujeitos epistemológicopolíticos não-institucionalizados, a constituição-legitimação-evolução das instituições e a construção dos possíveis caminhos da transformação social, tornando as instituições e esses caminhos totalmente politizados - criticismo social como práxis política, transformação social como práxis política direta, inclusiva e participativa. Por fim, o criticismo social como práxis política, fundado na e dinamizado pela politização abrangente, direta e radical das instituições, da práxis institucional-societal e dos sujeitos epistemológico-políticos permite romper-se a barreira entre instituições lógico-técnicas, autorreferenciais e auto-subsistentes e sociedade civil e esfera público-política enquanto arena-práxis político-normativa, assim como, em conseqüência, a contraposição e sobreposição entre técnicos e elites institucionais versus classes sociais, entre procedimentalismo institucional apolítico e lógico-técnico versus práxis política como luta social, como crítica e participação social.

\section{CRítiCA SOCIAL E PRÁXIS POLÍTICA: QUESTÕes E DESAFIOS EPISTEMOLÓGICO- POLÍTICOS PROGRAMÁTICOS}

Pensar o criticismo social como práxis política - isto é, defender-legitimar que a realização da crítica social tem como condição de possibilidade e como fundamento normativo a politização e a participação política permanentes, portanto acontecendo apenas como politização e participação diretas dos excluídos por eles mesmos e para eles mesmos, para além de certo modelo de objetividade e de neutralidade teóricas que, ao estilo do procedimentalismo institucional, separa o que é propriamente teoria e o que é propriamente práxis política, Realpolitik, como se separa política institucional-formal e participação política espontânea-informal com seus atores respectivos - apresenta certas questões e certos desafios epistemológico-políticos que queremos refletir a partir de agora. Em primeiro lugar, insistimos novamente, o criticismo social somente é possível como práxis política, o que exige politização permanente das lutas sociais, dos arranjos institucionais e dos sujeitos epistemológico-políticos, de modo a evitar-se e a desconstruir-se o institucionalismo forte em política que se baseia na e que leva à correlação entre instituições lógico-técnicas, de cunho autorreferencial e auto-subsistente, ao procedimentalismo institucional marcado por uma dinâmica de funcionamento e de legitimação e de constituição que é imparcial, neutral, formal e impessoal, e à tecnocracia política, no sentido de que instituições lógico-técnicas, autorreferenciais e auto-subsistentes, são estruturas-sujeitos-dinâmicas não-políticas e nãonormativas, administradas, geridas e legitimadas apenas por técnicos e elites institucionais e desde uma perspectiva eminentemente interna, fechada, autônoma e sobreposta à sociedade civil, à esfera público-política, suas classes sociais e suas lutas por hegemonia.

A politização permanente dos sujeitos epistemológico-políticos, das dinâmicasestruturações institucionais e dos sujeitos epistemológico-políticos institucionais e nãoinstitucionais tem como consequência a politização das instituições, seu procedimentalismo e 
seus sujeitos epistemológico-políticos, evitando-se, aqui, sua despolitização e tecnicização, contribuindo, assim, para deslocar o peso da legitimação institucional e da evolução social para a sociedade civil, a esfera público-política, canalizada e dinamizada pelas classes sociais como macrossujeitos epistemológico-políticos de alcance e sentido estrutural, com suas lutas por hegemonia (cf.: Rancière, 2014; Moraña, Dussel \& Jáuregui, 2008). Nesse sentido, em uma situação de politização direta das instituições, de seu procedimentalismo e de seus sujeitos epistemológico-políticos, bem como, correlatamente, no momento em que se situa essas mesmas instituições, seus sujeitos epistemológico-políticos e suas dinâmicas de funcionamento, de legitimação e de evolução dentro do horizonte político-normativo constituído pela sociedade civil e, aqui, pela esfera público-política, orientada e dinamizada e definida pelas lutas sociais por hegemonia entre sujeitos epistemológico-políticos antagônicos, tem-se a desconstrução daquela imagem, herdada da teoria de sistemas, de que as instituições são estruturas-sujeitos puros, basicamente instrumentais, de constituição e dinâmica lógicotécnica individualizada, auto-subsistente, fechada, autorreferencial, estruturas-sujeitos puros que em rigor seriam-apareceriam como autônomos em relação às lutas de classe e à hegemonia de classe. Da mesma forma, assumindo-se a politização das instituições, de suas dinâmicas e de seus sujeitos epistemológico-políticos formais, situando-os, portanto, no horizonte político-normativo da sociedade civil, de suas classes sociais e de suas lutas políticas por hegemonia, possibilita-se ao criticismo social como práxis política recusar o procedimentalismo institucional imparcial, neutro, formal e impessoal como práxis políticoinstitucional para a orientação-enquadramento das instituições, de suas relações com a sociedade civil e mesmo do modo como os sujeitos epistemológico-políticos da sociedade civil interagem com essas mesmas instituições e suas elites. Nesse sentido, o procedimentalismo institucional apolítico deixa de ser a base paradigmática para o criticismo social e para a participação política da sociedade civil e de seus sujeitos epistemológicopolíticos frente ao institucionalismo, de modo que, a partir de agora, a práxis política passa a ser percebida como luta política, como participação-problematização política abrangenge, direta e inclusiva em relação aos sistemas sociais de um modo geral e às instituições jurídicopolíticas em particular.

A politização permanente, abrangente e direta dos sistemas sociais, de suas dinâmicas procedimentais e de seus sujeitos epistemológico-políticos técnicos-formais possibilita, ainda e como conseqüência do que foi exposto acima, a superação de qualquer ranço de tecnicalidade e de objetividade puras relativamente ao entendimento-fundamentação do funcionamento e da constituição das instituições, à atuação de suas elites políticas e, finalmente, ao tipo de práxis política que pode legitimamente ser assumido pelos sujeitos epistemológico-políticos da sociedade civil e como sujeitos epistemológico-políticos não-institucionais. Como estamos dizendo, a dinâmica de constituição, legitimação e funcionamento das instituições, a própria noção de instituição ou de sistema social, o institucionalismo de um modo mais geral não pode ser explicado e muito menos transformado a partir da assunção da perspectiva lógico-técnica e, principalmente, a partir da aceitação de sua própria autorreferencialidade, de sua própria autosubsistência, de seu sentido interno e autônomo em relação à politização direta e abrangente. Isto quer dizer, em outras palavras, que a perspectiva crítico-emancipatória paradigmática para compreender-se a estruturação das instituições, sua dinâmica e elites internas e sua relaçãovinculação com a sociedade civil, seus sujeitos epistemológico-políticos e suas lutas não reside no institucionalismo como um fim em si mesmo, autônomo e sobreposto em relação a essa mesma sociedade civil, seus sujeitos epistemológico-políticos e suas lutas. Ora, as instituições, suas dinâmicas procedimentais e seus sujeitos epistemológico-políticos formais somente podem ser explicados a partir da tematização e da referência à sociedade civil, à esfera público-política, às classes sociais, suas lutas, hegemonia e contrapontos, posto que não existe um institucionalismo puro, lógico-técnico, autônomo, autorreferencial e auto-subsistente em relação à politização permanente possibilitada-realizada pelas classes sociais, suas lutas e contrapontos. É nesse sentido que somente pode haver criticismo social como práxis política radical, abrangente, permanente e inclusiva. É nesse sentido, inclusive, que não pode haver procedimentalismo institucional puro, apolítico, neutro, imparcial, formal e impessoal 
relativamente às lutas sociais entre-pelos sujeitos epistemológico-políticos da sociedade civil e em termos de esfera público-política. Aqui, como já dissemos de passagem acima, é uma questão de vida e de morte para o criticismo social como práxis política, para os sujeitos epistemológico-políticos marginalizados, excluídos e, por isso, crítico-emancipatórios da sociedade civil o evitar a tecnicização e a apoliticidade e a impessoalidade das instituições, de suas dinâmicas procedimentais e de seus sujeitos epistemológico-políticos informais.

Em segundo lugar, e como conseqüência do que vem sendo desenvolvido neste texto, o criticismo social como práxis política, como politização permanente, direta, radical e abrangente das instituições, de suas dinâmicas procedimentais e de seus sujeitos epistemológico-político formais por meio de sua localização dentro do e dependente do horizonte político-normativo constituído pela sociedade civil e em termos de esfera públicopolítica, por meio de sua ligação direta às classes sociais, suas lutas por hegemonia e os contrapontos daqui advindos, esse mesmo criticismo social como práxis política direta e politizadora deve romper com a separação entre teoria e prática que está por trás de um modelo de objetividade teórica pura e, como conseqüência, de práxis política asséptica que, como vimos dizendo, descamba diretamente para o institucionalismo forte, apolítico e lógicotécnico, autorreferencial e auto-subsistente, autônomo e sobreposto em relação às classes sociais e suas lutas. O criticismo social como práxis política deve estar para além, em confronto com esse ideal de objetividade teórica pura, o que também significa que ele deve enfrentar e superar o procedimentalismo institucional apolítico, imparcial, neutro, formal e impessoal como base paradigmática para o funcionamento-legitimação das instituições em relação a si mesmas, das instituições frente à sociedade civil e, finalmente, como base normativa, crítico-emancipatória para a atuação-enquadramento dos sujeitos epistemológicopolíticos da sociedade civil frente a si mesmos e em sua relação com as instituições e suas elites formais. A voz das vítimas, dos excluídos e dos marginalizados, nesse sentido, não admite tal pureza, formalismo e neutralidade teóricas, assim como não pode ser ouvidarealizada como procedimentalismo institucional-paradigmático de cunho impessoal e imparcial, senão que somente por meio da própria participação-fala-luta do oprimido contra complexos institucionais lógico-técnicos e instrumentais que despolitizam a vinculação socialpolítica-normativa das instituições e sua ligação e dependência para com sujeitos epistemológico-políticos em termos de Realpolitik (cf.: Freire, 1987, p. 16-32; 1981, p. 31-35; 2001, p. 31-52; Rancière, 2014, p. 63-66). A voz das vítimas-excluídos-marginalizados é práxis política direta, inclusiva, participativa e politizadora, voz-práxis que vincula as instituições, suas dinâmicas procedimentais e seus sujeitos epistemológico-políticos formais às lutas de classe, aos sujeitos epistemológico-políticos da Realpolitik, da sociedade civil. Com isso, argumentamos que o criticismo social enquanto práxis política direta, permanente, participativa e inclusiva, politizadora das instituições e de seus sujeitos epistemológicopolíticos, ao estar baseado na assunção da luta de classes e entre classes, permite superar a tradição platônica da objetividade a todo custo, ainda hoje assumida pelo e utilizada no procedimentalismo institucional jurídico-político imparcial, neutro, formal e impessoal das teorias sociais e filosofias políticas liberais e social-democratas. Essa objetividade apenas se dá por meio da práxis política e desde a voz-participação-luta dos oprimidos e marginalizados, por parte deles e para eles, não a partir de um paradigma normativo genérico ao estilo do mundo da vida ou da linguagem ou do trabalho. Esse mesmo criticismo social como práxis política direta, participativa, inclusiva e abrangente, ao eliminar a tecnicização e despolitização das instituições, de suas dinâmicas procedimentais e de seus sujeitos epistemológico-políticos formais, permite a localização, a encarnação e a politização - assim como a intencionalidade das classes sociais como sujeitos epistemológico-políticos, de suas lutas e de seus contrapontos, apontando para essa encarnação, intencionalidade e politização como os pontos centrais de qualquer análise social que já é e que já se manifesta como práxis política. Isso certamente elide qualquer perspectiva de objetividade pura, neutra e formal que se confunde com tecnicalidade, assim como de procedimentalização imparcial e impessoal das instituições, da práxis política e das classes sociais que se confunde com e descamba para o institucionalismo forte. 
Em terceiro lugar, a perspectiva-desafio central do criticismo social como práxis política direta, inclusiva e participativa consiste exatamente em tornar-se a voz-interpretaçãoação das vítimas e pelas próprias vítimas. Como as vítimas podem lutar? Quem são elas? Primeiro, as vítimas podem lutar desde uma perspectiva marginal, como práxis políticonormativa marginal e como sujeitos epistemológico-políticos marginais, isto é, anti-sistêmicos e anti-institucionalistas. Com efeito, talvez a mais básica definição de vítima ou excluído ou marginalizado, pelo menos quando se pensa em aspectos epistemológicos-políticosnormativos, consiste na percepção de que as vítimas estão às margens das instituições, portanto excluídas do sistema social. Nesse sentido, sua luta pode ser anti-sistêmica em um duplo aspecto: pode buscar a subversão do sistema social, a reestruturação das instituições como um todo e em perspectiva estrutural, ou pode integrar-se aos sistemas sociais ou instituições hegemônicos em um sentido reformista. Para nós, o criticismo social como práxis política emancipatória, participativa, direta e inclusiva tem lugar efetivamente como práxis política anti-sistêmica por sujeitos epistemológico-políticos não-institucionalizados, em que a luta social ganha centralidade e primazia frente ao procedimentalismo apolítico e imparcial enquanto institucionalismo forte, despolitizado e despolitizador, de modo que, da mesma forma, as classes sociais e suas lutas, como respectivamente sujeitos epistemológico-políticos não-institucionalizados e arena-práxis político-normativa informal, passam a primeiro plano em termos de dinamização e construção dos designs institucionais e de orientação dos processos de evolução social. De todo modo, esse sentido anti-sistêmico e anti-institucionalista da práxis política emancipatória como criticismo social, dos sujeitos epistemológico-políticos marginalizados e de sua luta sociopolítica aponta exatamente para a reconversãodesestruturação sistêmica que somente pode acontecer desde fora dos sistemas sociais autorreferenciais e auto-subsistentes, e como práxis político-normativa que supera, que desconstrói o sentido lógico-técnico e o procedimentalismo institucional apolítico que constituem o fundamento da dinâmica de constituição-legitimação-evolução dos sistemas sociais. Aqui reside o sentido primário das nossas afirmações sobre a práxis política de cunho crítico-emancipatório como participação-transformação anti-sistêmica e do sujeito epistemológico-político da práxis como o sujeito marginalizado, não-institucionalizado, alijado epistemológica, política e normativamente frente aos sistemas sociais e suas elites: as correlações entre sujeitos epistemológico-políticos marginalizados como sujeitos epistemológico-políticos não-institucionalizados, assim como da práxis político-normativa emancipatória com-como transformação desde as margens dos sistemas sociais e contra eles, significam que a transformação sistêmica, que é práxis político-normativa, ataca diretamente a dinâmica lógico-técnica, autorreferencial e auto-subsistente desses sistemas sociais, o que significa sua desestruturação-derrubada como estruturas-sujeitos-instituições puros, basicamente instrumentais, sem qualquer carnalidade-politicidade-normatividade; no mesmo diapasão, ela ataca também a tecnicização, a impessoalidade e a imparcialidade, o que significa a despolitização, do sujeito epistemológico-político dos sistemas sociais, das instituições, substituindo esse sujeito sem politicidade-carnalidade-intencionalidadenormatividade, basicamente lógico-técnico, pelas classes sociais e suas lutas, totalmente politizadas e politizantes. Isso significa também, como a afirmação anterior já salientou, que o procedimentalismo apolítico, imparcial e impessoal, que nega a práxis político-normativa como participação e ativismo inclusivo, direto e radical, que legitima a organização autorreferencial, auto-subsistente e lógico-técnica das instituições, é substituído pela luta de classes como a dinâmica balizadora e definidora daqueles designs institucionais e daqueles processos de evolução social. Aqui, a política e a crítica social - a política como crítica social, a crítica social como participação-ativismo político - retornam à práxis, como práxis, assumida e dinamizada pelas classes sociais e definida-orientada por suas lutas.

Note-se, reafirmamos mais uma vez, o sentido anti-sistêmico e anti-institucionalista do criticismo social como práxis política emancipatória dos excluídos e pelos excluídos: primeiro, ele se contrapõe diretamente à noção de institucionalismo forte, lógico-técnico e apolítico, recusando a autorreferencialidade, a auto-subsistência, a autonomia e a sobreposição desses mesmos sistemas sociais em relação às classes sociais e suas lutas, em relação à práxis política 
fundada em normatividade social; segundo, ele se contrapõe ao sentido lógico-técnico da constituição, da legitimação e da evolução dos sistemas sociais em relação a si mesmos e desde uma perspectiva interna, em um triplo sentido, (a) de que são instituições políticonormativas, de dinamização-funcionamento-legitimação profundamente interligado, dependente e definido pela sociedade civil e como esfera público-política, (b) de que os sujeitos epistemológico-políticos da dinamização institucional-societal não são apolíticos, imparciais e impessoais, não são estruturas-sujeitos-arenas puramente lógico-técnicos, instrumentais, senão que fundamentalmente políticos e externos às próprias instituições, enquanto classes sociais sediadas na e agindo desde a sociedade civil e sob a forma de esfera público-política, e (c) de que o procedimentalismo imparcial apolítico, lógico-técnico, autorreferencial e auto-subsistente não faz jus à politicidade-carnalidade-intencionalidade dos sujeitos epistemológico-políticos e de suas lutas sociais por hegemonia. Com isso, o criticismo social como a voz-práxis político-normativa das vítimas e pelas vítimas adquire esse sentido anti-sistêmico e anti-institucionalista exatamente por colocar em xeque a própria viabilidade de sistemas sociais ou instituições apolíticos e despolitizadores, autorreferenciais, autosubsistentes, autônomos e sobrepostos que instauram uma férrea, despolitizada e impessoal barreira entre instituições e sociedade civil, entre dinâmica interna dos sistemas sociais e esfera público-política, entre elites-técnicos institucionais e classes sociais, entre procedimentalismo institucional apolítico-imparcial-impessoal e lutas sociopolíticas de classe. Ora, o criticismo social como práxis político-normativa dos excluídos-marginalizados por eles mesmos é antisistêmico e anti-institucionalista, no mesmo sentido, porque a tudo politiza e publiciza, colocando a esfera público-política e a participação-crítica política ampliada, inclusiva e direta como a arena e a práxis político-normativas basilares para a legitimação-constituição-evolução institucional-societal, rompendo com a autorreferencialidade, a autonomia, a autosubsistência, a sobreposição e o fechamento estrutural dos sistemas sociais a partir da afirmação de sua estruturação lógico-técnica, não-política e não-normativa.

De todo modo, como queremos enfatizar aqui, o criticismo social como práxis político-normativa das vítimas e pelas vítimas - o que liga, imbrica ferreamente teoria e prática - é anti-sistêmico e anti-institucionalista por um motivo e por uma condição epistemológicopolíticos ainda mais fundamentais, que é o próprio sentido e o próprio tipo de atuação dos excluídos-marginalizados. Com efeito, sob o conceito de excluído-marginalizado desenha-se não apenas o tipo de estruturação institucional lógico-técnica, não-política e não-normativa que despolitiza e tecniciza grandes campos da evolução social e sua constituição-dinâmica institucionalizada, que também despolitiza e tecniciza a vida-dinâmica interna desses mesmos sistemas sociais, seus procedimentos e seu pessoal autorizado; sob o conceito de excluídomarginalizado apresenta-se também a condição desse excluído-marginalizado frente aos sistemas sociais ou instituições, seu papel nulo e marginal em relação a elas, o fato de que eles são descartáveis ou inúteis a esses mesmos sistemas sociais, bem como o tipo de práxis críticoemancipatória que esses mesmos excluídos-marginalizados efetivamente instituem como contraponto às instituições. Comecemos por esse segundo ponto. De fato, a atuação críticoemancipatória dos excluídos-marginalizados somente pode acontecer como práxis políticonormativa que, portanto, politiza os focos estruturais-institucionais e os sujeitos epistemológico-políticos formais-institucionalizados responsáveis pela exclusãomarginalização, ligando, portanto, os sistemas sociais ao todo político-normativo constituído pela sociedade civil e em termos de esfera público-política, retomando, assim, um modelo de sociedade enquanto totalidade político-normativa que efetivamente concebe os processos de evolução sócio-institucional desde um prisma holístico, estrutural, e com cunho políticonormativo. A práxis político-normativa, crítico-emancipatória dos excluídos-marginalizados não pode tecnicizar, despolitizar e individualizar os sistemas sociais; ela não pode torná-los autorreferenciais e auto-subsistentes, nem concebê-los em um sentido não-estrutural, como se uma instituição tivesse apenas efeitos de curto alcance, e não efeitos em nível macro geradores de dinâmicas sócio-institucionais e configuradores do status quo socialmente vigente. Da mesma forma, a práxis político-normativa e crítico-emancipatória dos excluídosmarginalizados não pode anonimizar, impessoalizar e imparcializar, sequer individualizar, os 
sujeitos epistemológico-políticos que, enquanto classes sociais, situam-se fora das instituições, na sociedade civil e sob a forma de lutas por hegemonia na esfera público-política, o que significa, nesse caso, que as instituições ou sistemas sociais são uma consequência daquelas lutas sociopolíticas entre classes sociais antagônicas por hegemonia.

Nesse sentido, a práxis político-normativa dos excluídos-marginalizados é não-técnica e política por excelência, na medida em que contrapõe-se e põe por terra a despolitização e a instrumentalização dos sistemas sociais e dos campos da reprodução humana que eles centralizam, monopolizam, tecnicizam e despolitizam; da mesma forma, a práxis políticonormativa dos excluídos é política e intencional exatamente por contrapor-se à impessoalidade-imparcialidade-neutralidade dos técnicos sistêmicos e dos sujeitos políticos formais, institucionalizados. A práxis político-normativa dos excluídos, em verdade, como vimos dizendo, acontece desde as margens das instituições ou dos sistemas sociais e como criticismo social e participação política diretos, radicais, inclusivos, o que coloca em xeque a autorreferencialidade e a auto-subsistência sistêmicas, o sentido lógico-técnico das instituições, o procedimentalismo institucional formal, neutro e apolítico, assim como a constituição-atuação imparcial e impessoal dos sujeitos epistemológico-políticos institucionalizados. Isso também significa que a práxis político-normativa dos excluídosmarginalizados é anti-sistêmica exatamente por recusar e desconstruir a autonomia, o fechamento e a sobreposição estruturais desses mesmos sistemas sociais, de seus procedimentos e de seus técnicos-elites em relação à sociedade civil, à práxis políticonormativa direta e politizante, às classes sociais e suas lutas. Em verdade, a própria condição sócio-política do excluído-marginalizado não admite outra alternativa que não a politização total das instituições e dos sujeitos epistemológico-políticos formais, a centralidade da práxis político-normativa marginal em relação ao institucionalismo e, por fim, o caráter críticoemancipatório dos excluídos-marginalizados frente aos sujeitos institucionalizados, às elitestécnicos sistêmicos. É também nesse sentido, portanto, que o criticismo social como práxis política inclusiva e direta dos excluídos-marginalizados e por parte deles também é antisistêmico e anti-institucionalista.

A nosso ver aqui está o grande desafio do criticismo social como práxis política direta e inclusiva dos excluídos e pelos excluídos, um desafio que se ramifica em alguns pontos programático-metodológico fundamentais, de todo modo imbricados e mutuamente dependentes. Em primeiro lugar, o desafio-tarefa de construir uma teoria social crítica que possa efetivamente contribuir na politização das instituições e dos sujeitos epistemológicopolíticos formais a partir da sua localização em termos de sociedade civil e de esfera públicopolítica, com sua vinculação às classes sociais enquanto sujeitos epistemológico-políticos e suas lutas por hegemonia como a arena-dinâmica da constituição-legitimação-evolução institucional-societal. A construção de uma teoria social crítica dos excluídos-marginalizados, para eles e por eles é, acreditamos nós, o ponto nodal de qualquer práxis política emancipatória - já Paulo Freire, no caso brasileiro, por exemplo, insistiu em uma noção de pedagogia do oprimido que fosse construída por esse mesmo oprimido a partir de suas especificidades, esforço e posição epistemológica-política-normativa (cf.: Freire, 1987). Ora, tanto o academicismo exagerado quanto suas conseqüentes objetividade, neutralidade, impessoalidade e logicismo, quando se trata das ciências humanas e sociais (cuja função é exatamente a construção dessa teoria social crítica dos oprimidos-excluídos-marginalizados, para eles, por eles) são minimizados e, ao cabo, superados exatamente pela correlação entre criticismo social e práxis política anti-sistêmica e anti-institucionalista dos oprimidos e por eles mesmos, posto que tal práxis encarnada, intencionada e politizada, fundamentalmente normativa, recoloca o exercício teórico de interpretação, de crítica e de transformação da Realpolitik no seu devido lugar, a esfera público-política cotidiana própria à sociedade civil, e aos seus efetivos sujeitos epistemológico-políticos, as classes sociopolíticas, com suas lutas, contrapontos e posições epistemológico-políticas conflitantes, conflitivas. Aqui, a participação-ativismo, a voz-práxis dos excluídos-marginalizados pelo sistema, pelas instituições, é que efetivamente permite o enquadramento, a crítica e a reorientação sistêmico-institucional. A construção de uma teoria social crítica como práxis política dos oprimidos-marginalizados-excluídos e para eles, 
portanto, permite-possibita e deve permitir-possibilitar a politização dos sistemas sociais, de sua dinâmica institucional e de seus sujeitos epistemológico-políticos, retirando-lhes o sentido lógico-técnico, apolítico, impessoal e imparcial relativamente à sociedade civil e à esfera público-política, às classes sociais e suas lutas. Como o próprio Paulo Freire bem reconheceu, o criticismo social enquanto pedagogia-práxis do oprimido precisa ser realizado por ele e para ele, e de modo anti-sistêmico e anti-institucional, vale dizer, de modo politizador, participativo e intencional, como práxis política direta e inclusiva.

O segundo desafio importante de uma teoria social crítica enquanto práxis políticonormativa dos oprimidos-marginalizados e para eles consiste em retomar e enfatizar a centralidade epistemológica, política e normativa, assim como metodológico-programática, da práxis cotidiana, da Realpolitik e, aqui, a tematização direta, como argumentaremos mais adiante, das classes sociais e de suas lutas como a base de fundamentação-dinamizaçãolegitimação institucional. É somente pela retomada-ênfase da práxis político-normativa como o fundamento de onde toda a dinâmica societal-institucional parte e de onde e para onde os sujeitos epistemológico-políticos, por meio de suas lutas e contrapontos, sempre se movimentam que é possível superar-se o institucionalismo forte em teoria social e filosofia política, rompendo-se, correlatamente, com a separação entre teoria e prática, instituições e vida social, sujeitos epistemológico-políticos institucionalizados e sujeitos epistemológicopolíticos não-institucionalizados, ligando-os indelevelmente e vinculando-os políticonormativamente. Somente a práxis político-normativa dos oprimidos e por eles mesmos, para eles mesmos, tem a importante contribuição epistemológico-política e programáticometodológica de superar o sentido lógico-técnico, autorreferencial e auto-subsistente dos sistemas sociais e, como consequência, a imparcialidade, impessoalidade, neutralidade e formalismo dos sujeitos epistemológico-políticos institucionalizados, politizando a tudo e a todos. Por meio da práxis e como práxis, os oprimidos-marginalizados-excluídos superam a apoliticidade dos sistemas sociais, suas dinâmicas e elites-técnicos, assim como sua (dos oprimidos-marginalizados-excluídos) configuração epistemológico-política marginal, assumindo protagonismo frente aos sistemas sociais, suas dinâmicas institucionais e elites políticas - e isso certamente não significa integração e despolitização, mas, como vimos dizendo, práxis político-normativa anti-sistêmica e anti-institucional que rompe com a lógica neutra, impessoal e imparcial e com a apoliticidade sistêmicas.

O terceiro desafio fundamental para uma teoria social crítica como práxis políticonormativa direta e inclusiva dos oprimidos-excluídos-marginalizados e por eles, que leva à politização radical dos sistemas sociais, de suas dinâmicas e de seus sujeitos epistemológicopolíticos formais, assim como à centralidade da práxis, das classes sociais e de suas lutas em termos de legitimação-dinamização-orientação dos designs institucionais e dos caminhos da evolução social, consiste em re-enfatizar e trabalhar novamente os conceitos de classe social, de oprimido-excluído-marginalizado e de lutas de classe. Ora, em primeiro lugar, é importante ressaltar que, a partir da utilização dos conceitos de classe social e de lutas de classe, está-se significando uma contraposição ao sentido lógico-técnico, autorreferencial e auto-subsistente, autônomo e sobreposto dos sistemas sociais em relação à práxis político-normativa e às classes sociais e suas lutas. Por conseguinte, aqui, os conceitos de classe social e de lutas de classe querem enfatizar a politicidade-carnalidade-intencionalidade das instituições, de seus sujeitos epistemológico-políticos, de suas dinâmicas e configurações, retomando, finalmente, a ligação dessas instituições e de seus sujeitos epistemológico-políticos com a sociedade civil e sob a forma de esfera público-política dinamizada pelas lutas sociais entre macrossujeitos epistemológico-políticos - não existem, nesse sentido, instituições autorreferenciais, autosubsistentes e lógico-técnicas, não políticas e não-normativas. Da mesma forma, ao se utilizar esses conceitos de classe social e de lutas de classe como contraponto à despolitização e à tecnicização dos sistemas sociais, de suas dinâmicas de funcionamento e de legitimação, bem como de seus técnicos, elites e relações com a sociedade civil, está-se apontando para um enfrentamento e para uma contraposição diretos seja ao procedimentalismo institucional apolítico, impessoal, imparcial, neutro e formal, seja ao anonimato e à individualização dos sujeitos epistemológico-políticos das sociedades democráticas complexas contemporâneas - 
não existem arena-práxis e sujeitos institucionais apolíticos, lógico-técnicos, mas sim exatamente político-normativos. Ora, nos três casos - instituições lógico-técnicas, procedimentalismo institucional apolítico e sujeitos epistemológico-políticos anônimos e individualizados - descamba-se direta ou indiretamente para o institucionalismo forte e apolítico, caracterizado pela centralização e monopolização institucional, e desde uma dinâmica interna e por meio de um sentido lógico-técnico, da própria constituição-legitimaçãoevolução das instituições e, depois, como consequência, para a própria orientação da evolução social, para o correto enquadramento-justificação das lutas sociais e dos sujeitos epistemológico-políticos da sociedade civil. Os conceitos de classe social e de lutas de classe, portanto, têm por objetivo (a) a politização dos sistemas sociais, suas dinâmicas impessoais e seus sujeitos epistemológico-políticos formais, (b) a ligação entre institucionalização e práxis política, com a localização do institucionalismo dentro do horizonte político-normativo constituído pela sociedade civil e como esfera público-política e, por fim, (c) a recolocação dos sujeitos epistemológico-políticos como macrossujeitos, como classes sociais de ação estrutural em termos de constituição-dinamização institucional-societal. Nos três casos, tem-se uma politização abrangente das instituições, de suas dinâmicas e dos sujeitos epistemológicopolíticos, que perdem qualquer noção de tecnicalidade, anonimato, impessoalidade e formalismo - características-chave das propostas conservadoras de cunho sistêmico, institucionalista e apolítico.

No mesmo diapasão, podemos conceber o conceito de excluído-marginalizadooprimido a partir do seu sentido e práxis anti-sistêmicos, anti-institucionalistas. O excluídomarginalizado-oprimido é um sujeito político-normativo que, enquanto tal, confronta e põe por terra tanto a configuração supostamente lógico-técnica dos sistemas sociais quanto sua dinâmica autorreferencial e auto-subsistente, basicamente interna. Da mesma forma, enquanto sujeito político dotado de carnalidade-pessoalidade-intencionalidade, o excluídomarginalizado-oprimido permite denunciar e superar a impessoalidade, imparcialidade, autonomia e sobreposição seja dos sistemas sociais em relação à sociedade civil, seja seu procedimentalismo imparcial e impessoal e neutro em relação à práxis política como lutas de classe, seja, além disso, a apoliticidade-impessoalidade-imparcialidade-neutralidade do sujeito epistemológico-político sistêmico, formal, institucionalizado. $\mathrm{O}$ excluído-marginalizadooprimido está às margens do sistema, como uma peça inútil e sem valor, como um sujeito epistemológico-político que, por não ter se adequado e sobrevivido à selva institucional, permite perceber, como antítese, o núcleo duro do sistema, a selvageria de suas dinâmicas e a impessoalidade-insensibilidade de suas elites - além disso, ele é excluído-marginalizado frente aos sistemas sociais e suas elites pelo fato de não entendê-los, pelo fato de não saber como administrar, gerenciar e fundamentar esses mesmos sistemas sociais desde um prisma lógicotécnico. Por isso, o excluído-marginalizado-oprimido nunca é - e nunca pode ser tecnicalidade, impessoalidade, imparcialidade. Ele é práxis político-normativa encarnada, pessoal e intencional, e somente pode constituir-se como crítica social na medida em que se transforma em sujeito da práxis, na medida em que é práxis político-normativa.

No mesmo sentido, a práxis político-normativa do excluído, como participação-luta política direta e inclusiva, apresenta outro ponto nodal que rompe com o institucionalismo lógico-técnico e com a impessoalidade, imparcialidade, neutralidade e formalismo seja do procedimentalismo institucional apolítico, seja dos sujeitos epistemológico-políticos institucionalizados-formais, que é exatamente a solidariedade. Com efeito, a solidariedade social é a conditio sine qua non primeiramente para a sobrevivência do excluídomarginalizado-oprimido: ele precisa de auxílio e deve auxiliar, ele precisa construir uma rede de mutualidade e de ajuda que religa, sob a forma de responsabilidade e de comprometimento, a complexa e político-normativa rede de relações sócio-institucionais e de sujeitos epistemológico-políticos informais; em segundo lugar, a solidariedade é o médium que interliga os excluídos-marginalizados-oprimidos como macrossujeito epistemológico-político da crítica social enquanto práxis política inclusiva, direta e participativa, posto que nenhuma luta social anti-sistêmica e anti-institucionalista consegue ter condições de êxito sem aglutinar a massa dos espoliados desde uma perspectiva-postura de solidariedade e cuidado recíproco, 
de atuação como classe com consciência de classe. A solidariedade social é anti-sistêmica e anti-institucionalista porque coloca o foco da crítica social como luta política na inclusão, na politização e na participação, rompendo com a centralidade da lógica sistêmica de autosubsistência a todo custo das instituições, para além das necessidades sociais e dos sujeitos epistemológico-políticos. Em suma, o excluído-marginalizado-oprimido somente pode

40 reerguer-se por meio da ajuda mútua, do reconhecimento mútuo, da solidariedade entre esses mesmos excluídos-marginalizados-oprimidos, que os leva a concertarem uma práxis políticonormativa como classe que, dotada de consciência de classe, a tudo enquadra desde uma perspectiva e de um sentido político-normativos. Ora, contrariamente a isso, um sistema social lógico-técnico, autorreferencial e auto-subsistente, de procedimentalismo interno que é impessoal, imparcial, neutro e formal, possui como dinâmica de funcionamento-legitimaçãoevolução basilar sua própria constituição lógico-técnica, não-política e não-normativa: como estrutura-sujeito puro, seu funcionamento e programação obedecem a um cunho lógicotécnico e são orientados à realização de objetivos lógico-técnicos por sujeitos lógico-técnicos que estão sobrepostos às exigências normativas e à práxis política dos valores de uso e, aqui, em termos de denúncia, confronto e superação da exclusão-marginalização-opressão. Um sistema social lógico-técnico, portanto, tem como única meta sua auto-subsistência ao longo do tempo por meio da afirmação de sua autorreferencialidade, de seu sentido e dinâmica internos.

\section{CONSIDERAÇÕES FINAIS}

À guisa de conclusão, o criticismo social como práxis político-normativa direta, inclusiva, participativa e solidária dos excluídos-marginalizados-oprimidos por eles mesmos deve afirmar exatamente seu sentido anti-sistêmico e anti-institucionalista, isto é, totalmente político e politizante, que supera o tecnicismo e a despolitização assumidos diretamente pelo conservadorismo político e indiretamente pela teoria social e pela filosofia política de cunho liberal e social-democrata, contrapondo-se ao procedimentalismo institucional apolítico, formal e neutro frente às classes sociopolíticas e às lutas sociais, rompendo também com a impessoalidade e imparcialidade dos sujeitos epistemológico-políticos institucionalizados em termos de constituição-legitimação-evolução institucional e societal. O institucionalismo lógico-técnico, o procedimentalismo apolítico e o sujeito epistemológico-político formalinstitucionalizado não servem como base paradigmática para pensar-se o criticismo social como práxis política que, pelo contrário, está fundado na e dependente da politização total, da participação política direta, inclusive e solidária dos excluídos-marginalizados-oprimidos desde a sociedade civil e como práxis político-normativa anti-sistêmica e anti-institucionalista. Nesse sentido, é preciso combater sem tréguas aquela correlação desenvolvida acima como base da atuação do conservadorismo político e como conseqüência do uso da teoria de sistemas e do procedimentalismo institucional apolítico por teorias sociais e filosofias políticas liberais e social-democratas, a saber: compreensão lógico-técnica de sistemas sociais autorreferenciais, auto-subsistentes, autônomos e sobrepostos, além de individualizados, em relação à sociedade civil, às classes sociais e suas lutas político-normativas por hegemonia; o procedimentalismo institucional apolítico, formal e neutro como base paradigmática para a orientação da dinâmica institucional e para o enquadramento e dinamização dos sujeitos epistemológico-políticos informais, não-institucionalizados; e, ainda, o sujeito epistemológicopolítico institucionalizado ou sistêmico enquanto imparcialidade e impessoalidade. É preciso, por conseguinte, situar e ligar de modo efetivo instituições e sociedade civil, dinâmica institucional e práxis política como luta social e sujeitos epistemológico-políticos institucionalizados com classes sociais. Aqui, a crítica e a emancipação, que somente acontecem como práxis político-normativa que é politizante e inclusiva, colocam exatamente a politização e a participação-ação política permanentes, dinamizadas por solidariedade social, como o elemento fundamental de denúncia, combate e superação da opressão, da marginalização e da exclusão geradas por sistemas sociais lógico-técnicos administrados e 
geridos por sujeitos epistemológico-políticos impessoais e imparciais desde um caminho institucional formal e neutro. As lutas sociais devem ser agudizadas, tornar-se pungentes, permanentes, se queremos superar a situação atual, em que percebemos a reafirmação do institucionalismo forte, lógico-técnico e apolítico por parte do conservadorismo político, uma forma de institucionalismo forte, lógico-técnico, apolítico, autorreferencial e auto-subsistente que deslegitima e nega a centralidade da práxis, dos sujeitos epistemológico-políticos da sociedade civil e em termos de esfera público-política, correlatamente levando à sobreposição e autonomização das instituições em relação à sociedade civil e à esfera público-política, à despolitização da práxis com sua consequente institucionalização neutra e formal, e à tecnicização, impessoalidade e imparcialidade dos sujeitos epistemológicos-políticosinstitucionais, por meio da negação da politicidade das classes sociais e de suas lutas, bem como da vinculação daqueles a estes.

\section{REFERÊNCIAS}

BENHABIB, Seyla; CORNELL, Drucilla (Eds.). Feminism as critique: on the politics of gender. Minneapolis: University of Minnesota Press, 1987.

BONDY, Augusto Salazar. Existe una filosofia en nuestra América? México: Siglo XXI, 1968.

BUTLER, Judith. Problemas de gênero: feminismo e subversão da identidade. Rio de Janeiro: Civilização Brasileira, 2003.

BUTLER, Judith. Undoing gender. London: Routledge, 2004.

BUTLER, Judith; SCOTT, Joan (Eds.). Feminist theorize the political. London: Routledge, 1992.

CORNELL, Drucilla. At the heart of freedom: feminism, sex, and equality. Princeton: Princeton University Press, 1998.

DUSSEL, Enrique. Ética de la liberación en la edad de la liberación y la exclusión. Madrid: Trotta, 1998.

DUSSEL, Enrique. 1492, o encobrimento do outro: a origem do mito da modernidade. Petrópolis: Vozes, 1993.

FANON, Frantz. Os condenados da Terra. Rio de Janeiro: Civilização Brasileira, 1968.

FORST, Rainer. Contextos da justiça: filosofia política para além de liberalismo e comunitarismo. São Paulo: Boitempo, 2010.

FRASER, Nancy. Fortunes of feminism: from State-managed capitalism to neoliberal crisis. London: Verso, 2013.

FREIRE, Paulo. Pedagogia do oprimido. Rio de Janeiro: Paz e Terra, 1987.

FREIRE, Paulo. Ação cultural para a liberdade e outros escritos. Rio de Janeiro. Paz e Terra, 1981.

FREIRE, Paulo. Política e educação. São Paulo: Cortez, 2001.

GIDDENS, Anthony. Para além da esquerda e da direita: o futuro da política radical. São Paulo: UNESP, 1996.

GIDDENS, Anthony. A terceira via: reflexões sobre o impasse da social-democracia. Rio de Janeiro: Record, 2000.

GIDDENS, Anthony. A terceira via e seus críticos. Rio de Janeiro: Record, 2001.

HABERMAS, Jürgen. Teoria do agir comunicativo: racionalidade da ação e racionalização social. São Paulo: Martins Fontes, 2012a.

HABERMAS, Jürgen. Teoria do agir comunicativo: sobre a crítica da razão funcionalista. São Paulo: Martins Fontes, 2012b.

HABERMAS, Jürgen. Direito e democracia: entre facticidade e validade (Vol. I). Rio de Janeiro: Tempo Brasileiro, 2003a.

HABERMAS, Jürgen. Direito e democracia: entre facticidade e validade (Vol. II). Rio de Janeiro: Tempo Brasileiro, 2003b.

HABERMAS, Jürgen. A inclusão do outro: estudos de teoria política. São Paulo: Edições Loyola, 2002a.

HABERMAS, Jürgen. $O$ discurso filosófico da modernidade: doze ensaios. São Paulo: Martins Fontes, 2002b.

HABERMAS, Jürgen. La constelación posnacional: ensayos políticos. Barcelona: Ediciones Paidós, 
2000.

HABERMAS, Jürgen. Ensayos políticos. Barcelona: Ediciones Península, 1997.

HAGGERTY, George E.; MCGARRY, Molly (Eds.). A companion to lesbian, gay, bisexual, transgender, and queer studies. New York: Wiley-Blackwell, 2007.

IRIGARAY, Luce. Yo, tu, nosotras. Madrid: Cátedra, 1992.

42 LUHMANN, Niklas. La sociedad de la sociedad. México: Herder, 2006.

MARCUSE, Herbert. Crítica da tolerância pura. Rio de Janeiro: Zahar Editores, 1970.

MBEMBE, Achille. On the postcolony. Berkeley and Los Angeles: University of California Press, 2001.

MBEMBE, Achille. Crítica da razão negra. Lisboa: Antígona, 2014.

MORAÑA, Mabel; DUSSEL, Enrique; JÁUREGUI, Carlos A. (Eds.). Coloniality at large: Latin American and the postcolonial debate. Duke: Duke University Press, 2008.

PARSONS, Talcott. A estrutura da ação social (vol. I). Rio de Janeiro: Editora Vozes, 2010a.

PARSONS, Talcott. A estrutura da ação social (vol. II). Rio de Janeiro: Editora Vozes, 2010b.

PARSONS, Talcott. The social system. London: Routledge, 1991.

PIKETTY, Thomas. O capital no século XXI. Rio de Janeiro: Intrínseca, 2014.

RANCIÈRE, Jacques. O ódio à democracia. São Paulo: Boitempo, 2014.

RAWLS, John. Uma teoria da justiça. São Paulo: Martins Fontes, 2000a.

RAWLS, John. Justiça e democracia. São Paulo: Martins Fontes, $2000 \mathrm{~b}$.

RAWLS, John. O liberalismo político. São Paulo: Ática, 2000c.

RAWLS, John. Justiça como equidade: uma reformulação. São Paulo: Martins Fontes, 2003.

RILEY, Denise. Am I that name? Feminism and the category of "women" in history. Minneapolis: University of Minnesota Press, 1988.

YOUNG, Iris Marion. Justice and the politics of difference. Princeton: Princeton University Press, 1990. 